
LIBRARY

University of

California

Irvine 


$$
\begin{aligned}
& 5 \\
& 521 \\
& B 18
\end{aligned}
$$




\section{Digitized by the Internet Archive in 2007 with funding from Microsoft Corporation}


THE OUTLOOK TO NATURE 


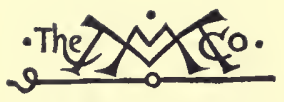

THE MACMILLAN COMPANY

NEW YORK - BOSTON - CHICAGO SAN FRANCISCO

\section{MACMILLAN \& CO., LimiteD}

LONDON - BOMBAY - CALCUTTA

MELBOURNE

THE MACMILLAN CO. OF CANADA, LTD. TORONTO 


\title{
The Outlook to Nature
}

\author{
L. ${ }^{b e r y} y_{\text {BAILEY }}^{\text {de }}$
}

NEW AND REVISED EDITION

Noxn 19ark

THE MACMILLAN COMPANY

I9 I I

All rights reserved 


\section{Copyright, 1905, 1911, BY THE MACMILLAN COMPANY.}

Set up and electrotyped. Published rgo5.

New and revised edition published February, 1911.

Norwood 7 ress

J. S. Cushing Co. - Berwick \& Smith Co. Norwood, Mass., U.S.A. 
TO

IDD Jfatber

WHOSE MORE THAN FOUR-SCORE AND TEN STURDY

YEARS HAVE BEEN LIVED ON THE FARM

- NATURALIST WITHOUT KNOWING IT-

II Deoicate tbis $5800 k$ 

THis book contains four lectures given in the Colonial Theatre, Boston, as a part of the University Course, under the auspices of the Education Committee of the Twentieth Century Club. The lectures were delivered in January, I905, although scheduled for a year earlier. Parts of the fourth lecture once appeared in The Independent.

$$
\begin{aligned}
& \text { IthaCA, N. Y., } \\
& \text { MarCh, I, } 1905 .
\end{aligned}
$$

These chapters have now been revised, and the book is re-set; and the size of the volume is reduced, for some of the incidental subjects are treated more fully in the other books now combined with it to make the Rural Outlook Set.

\section{H. BAILEY.}

November 8, 1910. 



\section{THE LECTURES}

I

PAGE

The Realm of the Commonplace - . - I-49

The spontaneous - The return to nature - It is not empty resignation - The out-of-doors The youthful life - The near-at-hand.

What Literature can do for $U_{s}$ (10).

The nature-writing - The newspaper — Real progress moves quietly - The farm is fundamental - Nature pictures in literary form The great writers - Nature poetry - Industry is poetic - We need new standards - Persons still like poetry - The resource of the silences. The Ways of Approach to Nature (30).

The nature companion - The weather - The common natural history - The ground - The heavens - The high places.

The Conclusion of the Whole Matter (49).

\section{II}

Country and City .

The proportion of farming people - The open country is essential - Compounded foods ix 
The city lives on the country - The country is making progress - Resiliency of the West - The open country has its own society The country school and college - The city galleries and collections - The out-door galleries. Countryman and City Man (68).

Two points of view - The sub-urban - The city obligation.

The Garden (74).

The garden room - The spirit of the garden. The Outlook for the Country (79).

The country home - Millinery architecture The need of social association - Reading for resource - The nature-ward tendency - The reverential attitude - The point of attack The poetical farmer.

We need the Country (9I).

We need the example of simple institutions - Not all the people should live on salary - We need the out-of-doors.

\section{III}

The School of the Future

Education for "culture" - Education for power - Application to life - Liberal education The humanities.

The School of Affairs (104).

The school of farm affairs. 


\section{The Lectures}

The New School (I 7 ).

PAGE

The new laboratories - The material of occupations - Manual training - The new program - We need equipment in land - The schoolgarden - The growing child — The natureattitude - The content-work - Self-expression - The result begins to be seen — The older subjects - Old phrases - The school of the future.

\section{IV}

Evolution: The Quest of Truth . . 138-195

The evolution hypothesis - Point of view of the discussion - Disproof by assumption - Disproof by misunderstanding - Evolution vs. transmutation - Evolution in operation.

Evidences of Evolution ( $15 \mathrm{I}$ ).

The species-bogey - The return to evidence Species-making in practice - The missing link - The tree of life - The underlying considerations - Direct considerations - The processes - Evolution in operation - Geographical differences - Darwin's conception.

Some Consequences of the Evolution Teaching (169).

The new attitude of mind - The new natural history - The new application of natural history - New attitude toward institutions and affairs - New attitude toward others - New attitude toward the quest of knowledge. 


\section{The Lectures}

An Evolutionist's Outlook (178).

It is not a verbal revelation - The search for God - Heaven - The vast program - The place of the individual — The truth shall make us free - Evolution and religion - The passing of fear and doubt - 'The outposts. 
THE OUTLOOK TO NATURE 



\section{THE OUTLOOK TO NATURE}

\section{I}

The Realm of the Commonplace

I SAT at the window of a hotel chamber,

1 musing at the panorama that comes and goes in a thousand cities. There were human beings pouring in and out, up and down, as if moved by some restless and relentless machinery. Most of them were silent and serious and went quickly on. Some sauntered, and returned again and again as if looking for something that they did not expect to find. Carriages went up and down in endless pageant. Trolley-cars rushed by, clanging and grinding as they headlonged into the side streets. Meretricious automobiles with gorgon-eyed drivers whirred into the crowds, scat- 
tering the street crossers. Men passed with banners and advertising placards. Women paraded with streaming headgear and tempestuous gowns. A resplendent trumpeter rolled by in a tallyho. A hundred other devices to attract the eye and distract the ear came out and vanished; and yet no one stopped and no one seemed to care. Now and then a knot of men would form, as some one fell or as wagons collided; but the knots as quickly dissolved, and I knew that they were made up of the idle, who were amused for the moment and then floated on hoping for fresh entertainment. A hurdy-gurdy attracted only a bevy of scurrying children. A little girl with armful of newspapers moved in and out unnoticed.

Suddenly a dog leaped down a flight of steps and was followed by two little children laughing and screaming. The dog felt his freedom and the children were in pursuit. The crowd stopped; the stern-faced men with high hats stopped; the well-dressed women stopped. Even a cabby pulled up his horse as the chil- 
dren dashed on the pavement after the escaping dog. Back and forth the children ran. On the far side of the street the people halted and took their hands out of their pockets. The children caught the dog and bundled it lovingly into the house; the crowd applauded, and dispersed.

Every person seemed to be surprised that he had stopped. From my height I thought I could discern the reason for such curious phenomenon: in all the blare and blazonry of that tumultuous thoroughfare, this was the only episode of real spontaneous and exuberant human nature. All else was a kind of acting, and every person unconsciously recognized that it was so. I thought how rare must common naturalness be, and how much has it been driven from our lives!

\section{The spontaneous.}

If a person has given any serious thought to public questions, he has his own contribution to make as to the causes of present conditions and the means of bettering them; so 
I make mine: what is now much needed in the public temper is such a change of attitude as will make us to see and appreciate the commonplace and the spontaneous, and to have the desire to maintain and express our youthful enthusiasms. And it is my special part to try, so far as possible, to open the eyes and the heart to nature and the common-day condition. My point of view is, of course, that of the countryman, and no doubt it has the countryman's bias.

So great has been the extension of knowledge, and so many the physical appliances that multiply our capabilities, that we are verily burdened with riches. We are so eager to enter all the strange and ambitious avenues that we overlook the soil at our feet.

We live in an age of superlatives, I had almost said of super-superlatives, so much so that even the superlatives now begin to pall. The reach for something new has become so much a part of our lives that we cease to recognize the fact, and accept novelty as a matter of course. If we shall fail to satisfy ourselves 


\section{The Commonplace}

with the new, the strange, and the eccentric, perhaps we shall find ourselves returning to the old commonplace and the familiar, and perhaps we shall be able to extract new delights from them because of the flights we have taken. Perhaps in their turn the commonplaces will be again the superlatives, and we shall be content with the things that come naturally and in due order. Certain it is that every sensitive soul feels this longing for something that is elemental in the midst of the voluminous and intricate, something free and natural that shall lie close to the heart and really satisfy his best desires.

\section{The return to nature.}

It is not likely that we shall greatly simplify our outward physical and business affairs. Probably it is not desirable that we should do so, for we must maintain our executive efficiency. We have seen a marvelous development of affairs, expressed in the renovation of a hundred old occupations and the creation of a thousand new ones. Most of these occupations 
are clear gain to the world, and we may expect them to endure.

This rise of affairs has emphasized the contrasts of business and of home. Machinery and intricacy belong to affairs; but a plainer and directer mental attitude should belong to our personal and private hours. The effective simplicity is not the lessening of physical conveniences and aids, but the absence of complex desires in eating and dress and entertainment and accessories, and in a native attitude toward life.

Perhaps our greatest specific need is a wholesome return to nature in our moments of leisure, - all the more important now that the moments of leisure are so few. This return to nature is by no means a cure-all for the ills of civilization, but it is one of the means of restoring the proper balance and proportion in our lives. It stands for the antithesis of acting and imitation, for a certain pause and repose, for a kind of spiritual temper, for the development of the inner life as contrasted with the externals. 


\section{The Commonplace}

It is not empty resignation.

Some persons have supposed that the "contentment" of the nature-lover implies unvexed indifference to the human affairs of the time, and that therefore it makes for a kind of serene and weak utopianism; but to my mind, the outlook to nature makes for just the reverse of all this. If nature is the norm, then the necessity for challenging and amending the abuses that accompany civilization becomes baldly apparent by very contrast. The repose of the naturelover and the assiduous exertion of the man of affairs are complementary, not antithetical, states of mind.

The recourse to nature affords the very means of acquiring the incentive and energy for constructive work of a high order; it enforces the great truth that, in the affairs of men, continued progress is conditioned upon a generous discontent and diligent unrest.

The outlook to nature is the outlook to optimism, for nature is our governing condition. Men look upward and outward to nature. 
The out-of-doors.

By nature, I mean the natural out-of-doors, - the snow and the rain, the sky, the plants, the animals, the garden and the orchard, the running brooks, and every landscape that is easy of access and undefiled.

Every person desires these things in greater or lesser degree : this is indicated by the rapidly spreading suburban movement, by the vacationing in the country, and by the astonishing multiplication of books about nature. Yet there are comparatively very few persons who have any intimate contact with nature, or any concrete enjoyment from it, because they lack the information that enables them to understand the objects and phenomena.

\section{The youthful life.}

Our eager civilization prematurely makes us mentally old. It may be true that the span of man's life is increasing, but at twenty we have the knowledge and the perplexities that our grandfathers had only at forty. Our children may now be older when they are graduated 


\section{The Commonplace}

from school, but the high-school course of today is more complex than was the college course of fifty years ago. All this has a tendency to lessen the years of free and joyous youth.

You have only to see the faces of boys and girls on your city streets, to discover how old the young have grown to be. In home and school our methods have been largely those of repression: this is why the natural buoyant outburst that I described for a city thoroughfare challenged such instant attention and surprise. We need to emphasize the youthful life; and a man or woman may have a youthful mind in an old body.

\section{The near-at-hand.}

Therefore, I preach the things that we ourselves did not make; for we are all idolaters, - the things of our hands we worship. I preach the near-at-hand, however plain and ordinary, - the cloud and the sunshine; the green pastures; the bird on its nest and the nest on its bough; the rough bark of trees; the frost on bare thin 
twigs; the mouse skittering to its burrow; the insect seeking its crevice; the smell of the ground; the sweet wind; the silent stars; the leaf that clings to its twig or that falls when its work is done.

Wisdom flows from these as it can never flow from libraries and laboratories. "There be four things," say the Proverbs, "which are little upon the earth, but they are exceeding wise :

"The ants are a people not strong, yet they prepare their meat in the summer;

"The conies are but a feeble folk, yet make they their houses in the rocks;

"The locusts have no king, yet go they forth all of them by bands;

"The spider taketh hold with her hands, and is in kings' palaces."

\section{What Literature can do for Us}

Some of us do not enjoy nature because there is not enough sheer excitement in it. It has not enough dash and go for this electric age; and this is the very reason why 


\section{The Commonplace}

we need the solace and resource of nature so much.

I am led to these remarks on looking over the lists of Christmas books, and finding myself challenged with the recurrence of the word "sensation." In the announcement of the forthcoming number of a magazine, I find twenty articles, of which at least nineteen are to be "tragic," " thrilling," " mystery-laden," or otherwise worth buying. The twentieth one I hope to read.

One would think that a piece of writing is valuable in proportion as it is racy, exciting, startling, astounding, striking, sensational. In these days of sensational sales, to have a book sell phenomenally well is almost a condemnation of it. An article or book that merely tells a plain story directly and well is too tame; so even when we write of nature we must pick out the unusual, then magnify and galvanize it. From this literature the reader goes out to nature and finds it slow and uninteresting; he must have a faster pace and a giddier whirl of 
events. He has little power to entertain himself; and, his eyes never having been trained to see what he looks at, he discovers nothing and the world is void. He may find temporary relief in some entertainment provided for him out of hand, as the so-called news of the newspapers or some witless frippery on the stage.

Yet, unless the poets and philosophers have misled us, the keenest delights that men have found have been the still small voices of the open fields.

The nature writing.

This is a real objection to much of the nature writing, - the fact that it is unrepresentative of nature. It exploits the exceptional, and therefore does not give the reader a truthful picture of common and average conditions. This has been true to some extent even of textbooks, — they choose so-called "typical" forms and structures, forgetting that typical examples exist only in books for purposes of definition. 
The good nature writing, as I conceive of it, is that which portrays the commonplace so truthfully and so clearly that the reader forthwith goes out to see for himself. Some day we shall care less for the marvelous beasts of some far-off country than for the mice and squirrels and birds and woodchucks of our own fields and for the cattle on our hills.

If I were a naturalist, I should go forthwith to study the mice and then write of them for all children; for, of all untamed animals, what ones are known to a greater number of children? - and yet what do the children know except that they have been early taught by their elders to dislike or even to fear these entertaining animals? The embodiment of all agility, of all quick dispatch, of all neat habits and of comeliness, of unseen and devious ways, is the mouse. What other object was ever so swift and silent and graceful as it slides along the corners of your room as intangible as a shadow! What explorer was ever so successful as it peers into drawers and sniffs in cupboards! 


\section{4 \\ Outlook to Nature}

In my boyhood the field mice were a constant source of entertainment and mystery. I found them scuddled in the corn shocks, burrowed in the dry grass, nesting in the corn-crib. I saw their faint narrow trails on new-fallen snow, leading into strange pygmy caverns.

\section{The newspaper.}

Just now I said something of the "news." It is important that we recur to this subject, since we are a people of news readers, and continuous reading strongly, though silently, influences our outlook to nature and affairs.

Much of what is called news is so unimportant that it is not worth the while of a person whose time is of value; but my chief objection to it, as to some of the nature writing, is that it is no way representative of human affairs, - if it were, I suppose it would not be new and therefore would not be news. It is made up to a large extent of exceptional and meaningless episodes and extravagancies.

Yesterday I saw hundreds of persons on cars and ferries eagerly reading the "news." I 
bought a paper resplendent with photography and colored ink. The first page had eight articles, seven of which were devoted to cases of divorce, common rascality and crime, and unimportant local accidents, all displayed as if it would advantage a man to read them. Only one article dealt with public affairs, and this was hidden underneath small headlines. The newspaper had no sense of proportion. All the detail of a divorce case was given with as much circumstantial minuteness as if it were of equal importance with a debate in Congress or the deliberations of the international peace conference.

As I was about to write these sentences, I chanced to pick up the following editorial paragraph from a country newspaper (The Seneca Falls, N. Y., "Reveille"):

"The sound and wholesome qualities which make for all that is most prized in life are to be found in the great masses of the people, and are scarcely touched by the currents of the time which make for evil, and with which the news of the day is necessarily so largely concerned. 
It is not the doings or the ways of the great bulk of the people - those who quietly earn a modest living by ordinary industry - that furnish much material either for news or for comment. We take all that for granted, and when we think of the tendencies of the time, we almost forget its existence. When a touch of nature happens to bring into unaccustomed relief the existence of the homely but sturdy and sterling virtues of the great American people, their rightmindedness and true-heartedness, it is.well to draw from the event the lesson that manhood and merit are after all the things which create the very best character for our country and government."

Real progress moves quietly.

We gather from this extract the opinion that what we call the "slow" and "dull " may, after all, be the saving strength of a people. In the hamlets and villages and small country cities, great problems are working themselves out just as effectively as in the mighty cities; and although slowly, or even because slowly, they may be 


\section{The Commonplace}

working out more fundamentally than elsewhere. The great mass of mankind is unrecorded and practically unknown. A few of us are actors, and we pass with some noise and flourish across the stage; but the sources of events are behind and beyond. I have heard the saying attributed to a statesman that if the discussions either at the country four-corners or in the President's Cabinet were to cease, it were better to do away with the Cabinet. Public opinion does not seem to originate to any extent with the leaders: the leaders are more likely to catch and voice the crystallizing sentiments of the commonplace, originating slowly and perhaps unconsciously with those who work first-handed with the forces that make for prosperity.

It is too bad that all this may not be reflected in our common literature.

The farm is fundamental.

We might go even farther than the hamlet or the town, - to the family unit on the remotest farm. This unit is considered by most of 
the other members of the race to be the commonplace of the commonplace; yet, along with the farming, human problems are being worked out. There boys and girls are being reared and even trained, who some day may come to your cities and distance your own sons and daughters; for it is a discouraging fact that, with all we are doing for schooling, merit and efficiency do not seem to increase in proportion, and those whom we are in the habit of calling uneducated may take the highest prizes that the world has to give.

The farm, in its turn, is being exploited in our current literature; and, significantly enough, much of this literature is of the sensational order. Of all things to be sensationalized, the farm should be the last. The farm need not be prosaic nor devoid of good intellectual interest; but its very spirit is that of constancy.

We should stimulate the ideals in every occupation; but the ideal should follow closely the facts and the spirit of the real. We need to idealize the commonplace, for then we show its 


\section{The Commonplace}

possibilities. When we develop the ideals in farming, we shall add a great resource to our people.

Nature pictures in literary form.

We need a new literature of nature and the open country, a literature that shall not be lifelessly descriptive. We need short, sharp, quick, direct word-pictures that shall place the object before us as vividly as the painter would outline some strong simple figure with a few bold strokes of his brush; and it is not essential to the truth of the picture that a rhetorical climax be added. It may not be necessary even to make a "point," but only to bring the picture before the mind.

Every object and every common labor awaken some response beyond themselves, and this response can be set to words. The man employed at useful and spontaneous work is a poetic figure, full of prophecy and of hope. The cow in the field, the tree against the sky, the lands newly plowed, the crows flapping home at night, the man at his work, the woman 
at her work, the child at its play - these all are worth the stroke of the artist.

I saw a man walking across the fields, with spade on his shoulder and dog at his side; I saw his firm long stride; I saw his left arm swing; I saw the weeds fall beneath his feet; I saw the broad straight path that he left in the grass. There were brown fields, and woods in the first tint of autumn. I saw birds; and in the distance was the rim of the sky. And beyond him, I saw the open ditch to which he was returning.

\section{The great writers.}

With the nature writers I like to include some of the authors who do not write specific natural history topics. If they write from the out-of-doors, with a keen love of it and a knowledge of what it comprises, adding to it touches of good human nature, then they lead men to the open as effectively as those to whom we customarily apply the term "nature writer." The landscape is as important as any object that it contains, and the human sentiment is more important than either. 


\section{The Commonplace}

These writers invariably write the commonplace, and touch it into life and meaning. One of the greatest of these writers, to my thinking, is Stevenson, - simple, direct, youthful, tender, and heartsome. His life was with nature; his work touches the elemental.

O Stevenson! On far Samoa's tropic shore

You moored your slender bark,

And there in calm secludedness did live

To write the spirit of your gentle soul

And over all the world to pour

The fragrance from the tropic of your heart.

And thence you passed beyond, -

Passed not with the proud acclaim

Of pageant and tempestuous bells

That drown themselves in blank forgetfulness, -

But fell away as falls the wind at eventide;

And all the trees on all the isles and shores

Bowed their heads in solitude.

\section{Nature poetry.}

I like to think that some of our poetry is also leading us nature-ward in a very practical way, since it is becoming more personal and definite, and brings us into closer touch with 
specific objects and demands greater knowledge of them. It has been the progress of our attitude toward nature to add the concrete to the abstract; and this may be expected to proceed so far that every object of the environment and every detail of our lives will be touched with inspiration. If I cannot catch a note of inspiration from the plainest thing that $I$ touch, then to that extent my life is empty and devoid of outlook.

The great voices appealed to the early Greeks, - the thunder, the roaring wind, the roll of the waves, the noise of war; but we do not know that the shape of the leaf, and the call of the young bird, and the soft gray rain appealed much to them. The Greek lyrics are mostly personal or personifying, and lack any intimate touch with the phases of natural phenomena. As men have come more and more to know the near-at-hand and the real in nature, this knowledge has been interpreted in the poetry; for poetry always reflects the spirit of the time. All English poetry illustrates this general tendency; but what we are in the habit of calling 


\section{The Commonplace}

"nature poetry" is of comparatively recent growth. It is to be hoped that we shall never have less nature poetry that expresses the larger moods; but we must have more that is specific as to natural history facts, and which will still be poetry.

The individual seems sometimes to recapitulate the development of the race: as each of us grows old and conventionalities lose their meaning and the small voices make a stronger appeal, we are conscious that we have had Wordsworth's experience :

" In youth from rock to rock I went, From hill to hill in discontent, Of pleasure high and turbulent, Most pleased when most uneasy; But now my own delights I make, My thirst from every rill can slake, And gladly Nature's love partake Of thee, sweet Daisy!"'

Industry is poetic.

It is often said that as this is a practical age, with industrialism extending everywhere, 


\section{Outlook to Nature}

therefore poetry must die away. Nothing could be farther from the truth.

It is true that industrialism is developing at great pace; this, in fact, is the glory of our time, for civilization has entered on a new epoch. Men's minds are concerned with things that never concerned them before; yet, the resources of the old earth have merely been touched here and there, and the wealth of mankind will increase. But all this does not mean that sentiment is to be crushed or that the horizon of imagination is to be contracted, but rather the reverse. It is only by the exercise of vast imagination that the great conquests of our time are being won. The flights of science and of truth are, after all, the flights of fancy.

We need new standards.

We need the poetry of the new kind. Perhaps the day of the formal "sustained" poem has passed, - with its ambitious disquisitions, long periods, heavy rhetoric, labored metaphors. It is a question, also, whether 


\section{The Commonplace}

even the sonnet, although highly artistic, is free and strong enough to express the naturefeeling of our time; for this feeling seems to be more and more impatient of historical forms. The new nature poetry must be crystal clear, for we have no time for riddles, even though they are set in meter and rhyme. It must be definite, and it must apply.

The best nature poetry will be hopeful, joyous, and modern. At least some of it will deal with objects, phenomena, and emotions that are common to common men, that it may become a part of men's lives. Perhaps this more vital song will relieve poetry writing of much that is too theoretical and fine-spun; and I hope that it may also divert the current from the petty lovelorn type of verse-making which exploits personal love affairs that ought to be too private and sacred, as they are also too small, for publication.

This poetry, whether its flight is small or great, must be born of experience, and must be intrinsic; it must be the expression of a full heart, not the sentiment of a looker-on. The 
nature poem of wide reach must be the poem of the man who is free. Such poetry must spring from the open air; perhaps it must be set to words there, - at least outside the city. The city will have its great poems, but they will rise out of the city as Venus rose out of the sea.

It seems to me that we have really very little genuine nature poetry (a subject to which I shall refer again in my fourth lecture). Our poets, in spirit or in fact, now write largely from the city and the study outward, and their work is bookish. The product is too often the "cultured" poetry of the literary cult, under the influence of tradition. It continues to be burdened with useless metaphor, and it follows conventional forms of verse and line, as if verse and line were more than essence. Literary criticism still looks backward rather than forward, and much of its criterion is not applicable to present-day conditions. We must face toward the future. Walt Whitman - poet of the commonplace - has most.completely freed himself from the bondage of literary form ; and he is only an earnest of what shall come. 
It is doubtful whether the great nature poet will be taught in the formal curricula of the schools. His spirit and his method will be as unconfined as the farm lands, the inaccessible mountains, the great plains, or the open sea.

The old-time short nature poem was wont only to point a moral, - usually dubious and far-fetched and factitious, - having little vitality of its own. It really was not a nature poem, for the real nature poem is its own moral. The poems and stories of the Old Testament are always interesting because they have something to say, they are direct, not heavy with adjectives or with rhetoric, and they are moral because they tell the truth.

Persons still like poetry.

I am constantly surprised at the poems that busy and practical men know; and also at the poetry that many busy men can write. There is reason to believe that there were never so many poets in the world as now. Poetry-making is not an occupation, but the incidental spark that strikes off from useful labor; it is 
the result of full and serious lives. The roll of machinery is rhythm and rhyme; the blowing of the wind is music.

It has been my good fortune to have had many years' experience in the teaching of farm boys. They are interesting boys, - strong, virile, courageous. They have had the tremendous advantage of having been let alone, and of having developed naturally. They hold their youth. It is my habit to call these agricultural students together frequently, and, amongst other exercises, to read them poetry. Usually at first they are surprised; they had not thought of it before; or they thought poetry is for girls: but they come again. They may hide it, but these farm boys are as full of sentiment as an egg of meat. There was one fellow who had to support himself and help members of his family. He was a good student, but the lines of his life had been hard. Whenever he called at my office it was to ask advice about money affairs or to tell me of difficulties that he feared he could not overcome. Apparently there was no sentiment in his life, 


\section{The Commonplace}

and no room for it. One evening I read to the students Matthew Arnold's "Buried Life." The next day, Jenkins came to my office, entered hesitatingly as if requesting something that he might not have, and asked whether I would loan him the poem till he could learn it, for he could not afford to buy.

If sentiment is necessarily eliminated from business transactions, it is all the more important that it be added to the recreation and the leisure. The world never needed poetry so much as now. This thought is forcibly expressed in Charles Eliot Norton's advice, that has now been so effectively used by the press: "Whatever your occupation may be, and however crowded your hours with affairs, do not fail to secure at least a few minutes every day for refreshment of your inner life with a bit of poetry."

The resource of the silences.

We need now and then to take ourselves away from men and the crowd and conventionalities, and go into the silence, for 
the silence is the greatest of teachers. Walt Whitman expresses this well:

" When I heard the learn'd astronomer, When the proofs, the figures, were ranged in columns before me,

When I was shown the charts and diagrams, to add, divide, and measure them, When I sitting heard the astronomer where he lectured with much applause in the lectureroom,

How soon unaccountable I became tired and sick, Till rising and gliding out I wander'd off by myself,

In the mystical moist night-air, and from time to time Look'd up in perfect silence at the stars."

\section{The Ways of Approach to Nature}

It will be gleaned from what has been said that we are to consider literature, including poetry, to be one of the means of the enjoyment of nature. It is fundamentally important, however, that we regard literature only as a means : it is not nature.

One can never be fully appreciative of this natural world unless he has technical knowl- 
edge of some special part of it. One assuredly cannot be zoölogist, geologist, botanist, and meteorologist; but if he has intimate personal knowledge of one limited part, he has the key to the whole. The person must have pursued some branch of natural history for a time with serious purpose, - the purpose to discover and to know the subject-matter for himself. This gives him point of view; tells him what to look for; enables him to look beneath the surface; trains his judgment as to causes and effects; guides him in distinguishing the essential; saves him from error.

But before one takes up any serious bit of study for himself, he must have the wish to take it up. In every person there is a latent desire to know something of the enclosing world, but it is usually ironed out in the laundering processes of the schools and the misdirections of the home. In some persons this native desire is so strong that nothing extinguishes it: these persons become professional investigators and widen the boundaries of knowledge. Most of us, however, must 
give our main thought to other matters, and let the outlook to nature be chiefly a wellguided affection.

\section{The nature companion.}

The best possible introduction to nature is that afforded by a sympathetic person who knows some aspect of nature well. You imbibe your friend's enthusiasm at the same time that you learn birds, or plants, or fishes, or the sculpturing of the fields. By enthusiasm I mean never exclamation, but that quiet and persistent zeal that follows a subject to the end for the love of it, even though it take a month. This person need not be a professed "scientist," unless he is also a good teacher and knows what is most important in the subject and most relevant to you. The earlier the child has such a guide - if arrived at the age of reason - the more vital and lasting the effect: even one or two excursions afield may change the point of view and open the way for new experiences, although neither the guide nor the child may be aware of it at the time. The 


\section{The Commonplace}

ideal guide was "Gramp," as James Buckham knew him ("Country Life in America"):

"What a man to fish and camp, What a hand to hunt and tramp Up and down the woods, was Gramp!

" How he led me, high and low, Plunging through the brush and snow! Boy-like, how I loved to go!

"Oh, the sweet days that we spent In the forest's pure content! Oh, the long, still miles we went!

" Keen-eyed Gramp! How well he knew Where the biggest berries grew, Where the witch-like woodcock flew!

" Learned was he in all the lore Of the wood-wise men of yore Subtle knowledge, taught no more.

"Ah, a happy boy was I, Loving God's free woods and sky, With dear Gramp to teach me why!"

\section{The weather.}

That which is first worth knowing is that which is nearest at hand. The nearest at hand, 


\section{Outlook to Nature}

in the natural surroundings, is the weather. Every day of our lives, on land or sea, whether we will or no, the air and the clouds and the sky environ us. So variable in this environment, from morning till evening and from evening till morning and from season to season, that we are always conscious of it. It is to the changes in this environment that we apply the folk-word "weather," - weather, that is akin to wind.

No man is efficient who is at cross-purposes with the main currents of his life; no man is content and happy who is out of sympathy with the environment in which he is born to live: so the habit of grumbling at the weather is the most senseless and futile of all expenditures of human effort. Day by day we complain and fret at the weather, and when we are done with it we have - the weather. The same amount of energy put into wholesome work would have set civilization far in advance of its present state. Weather is not a human institution, and therefore it cannot be "bad." I have seen bad men, have read bad books, have made bad 


\section{The Commonplace}

lectures, have lived two years about Boston, but $I$ have never seen bad weather!

"Bad weather" is mainly the fear of spoiling one's clothes. Fancy clothing is one of the greatest obstacles to a knowledge of nature: in this regard, the farm boy has an immense advantage. It is a misfortune not to have gone barefoot in one's youth. A man cannot be a naturalist in patent-leather shoes. The perfecting of the manufacture of elaborate and fragile fabrics correlates well with our growing habit of living indoors. Our clothing is made chiefly for fair weather; when it becomes worn we use it for stormy weather, although it may be in no respect stormy weather clothing. I am always interested, when abroad with persons, in noting the various mental attitudes toward wind; and it is apparent that most of the displeasure from the wind arises from fear of disarranging the coiffure or from the difficulty of controling a garment.

If our clothes are not made for the weather, then we have failed to adapt ourselves to our conditions, and we are in worse state than the 
beasts of the field. Much of our clothing serves neither art nor utility. Nothing can be more prohibitive of an interest in nature than a millinery "hat," even though it be distinguished for its floriculture, landscape gardening, and natural history.

Our estimate of weather is perhaps the best criterion of our outlook on nature and the world. The first fault that I would correct in mankind is that of finding fault with the weather. We should put the child right toward the world in which he is to live. What would you think of the mariner who goes to sea only in fair weather? What have not the weather and the climate done for the steadiness and virility of the people of New England? And is this influence working as strongly today as in the times when we had learned less how to escape the weather? We must believe in all good physical comfort, - it contributes to the amount of work that we can accomplish ; but we have forgotten that it is possible to bear an open storm with equanimity and comfort. The person who has never been caught in rain 


\section{The Commonplace}

and enjoyed it has missed a privilege and a blessing.

Give us the rain and the hail and the snow, the mist, the crashing thunder, and the cold biting wind! Let us be men enough to face it, and poets enough to enjoy it. In "bad" weather is the time'to go abroad in field and wood. You are fellow then with bird and stream and tree; and you are escaped from the crowd that is forever crying and clanging at your heels.

The common natural history.

The first consideration of special study should be the inhabitants of your yard and garden: they are yours; or if they are not yours, you are not living a right life. Do you wish to study botany? There are weeds in your dooryard or trees on your lawn. You say that they are not interesting: that is not their fault.

We have made the mistake all along of studying only special cases. We seem to have made up our minds that certain features are 
interesting and that all other features are not. It is no mere accident that many persons like plants and animals but dislike botany and zoölogy. It is more important to study plants than special subjects as exemplified in plants. Why does the weed grow just there? Answer this, and you have put yourself in pertinent relation with the world out-of-doors.

If one is a farmer, he has the basis for his natural history in his own possessions, - animals domestic and wild, plants domestic and wild, free soil, pastures and lowlands and woodlands, crops growing and ripening, the daily expression of the moving pageant of nature. Zoölogical garden and botanical garden are here at his hand and lying under his title-deed, to have and to hold as he will. No other man has such opportunity.

I would also call the attention of the townsman to his opportunity. If the range of nature is not his, he still has the wind and rain, the street trees, the grass of lawns, the weed in its crevice, the town-loving birds, the insects, and I hope that he has his garden. Even the city 


\section{The Commonplace}

has its touch of natural history - for all things in the end are natural, and we recognize them if we have had the training of a wholesome outlook to the commonplace. Timrod's sonnet on the factory smoke is a nature-note:

“I scarcely grieve, O Nature! at the lot That pent my life within a city's bounds, And shut me from thy sweetest sights and sounds. Perhaps I had not learned, if some lone cot Had nursed a dreamy childhood, what the mart Taught me amid its turmoil; so my youth Had missed full many a stern but wholesome truth. Here, too, O Nature! in this haunt of Art, Thy power is on me, and I own thy thrall.

There is no unimpressive spot on earth!

The beauty of the stars is over all, And Day and Darkness visit every hearth. Clouds do not scorn us : yonder factory's smoke Looked like a golden mist when morning broke."

\section{The ground:}

I would preach the surface of the earth, because we walk on it.

When a youth, I was told that it was impossible for me to study geology to any purpose, because there were no outcroppings 
of rocks in my region. So I grew up in ignorance of the fact that every little part of the earth's surface has a history, that there are reasons for sandbanks and for bogs as well as for stratified rocks. This is but another illustration of the old book-slavery, whereby we are confined to certain formal problems, whether or not these problems have any relation to our conditions. I well remember what a great surprise it was to learn that the sculpturing of the fields can be understood, and that the reasons for every bank and swamp and knoll and mudhole can be worked out.

There was a field back of the barn that contained hundreds of narrow knolls, averaging three to four feet high. At one side of every hummock was a narrow deep pocket that until midsummer was filled with water. The field was so rough that it could not be plowed, and so it was continuously used as a pasture. It was an Elysian field for a boy. Every pool was a world of life, with strange creatures and mysterious depths, and every knoll was a point of 
vantage. Near one edge of the field ran a rivulet, and beyond the rivulet were great woods. What was beyond the woods, I could only surmise. I recall how year by year I wondered at this field, until it became a sort of perpetual and compelling mystery, and somehow it came to be woven as a natural part of the fabric of my life. To this day I try once each year to visit this dear old field, even though it is long since leveled. All the sweep of my childhood comes back to me unbidden. The field is still a pasture, and generations of cows have passed on since then. Yet, as much as this field meant to me, I do not remember to have had any distinct feeling that there was any cause for the pools and knolls. My father cut the field from the forest, yet I do not remember that I ever asked him why this field was so; and I never heard any person express any curiosity about it. We all seemed to have accepted it, just as we accept the air. As I think of it now, this field must have been the parh of a tornado that turned over the trees; and long before the settlers came, the 
prostrate trunks had decayed and a second forest had grown. Would that I could have known that simple explanation! One sentence would have given me the clew. How the mystery of the ancient tornado and the rise of another forest would have conjured a new world of marvel and discovery!

When I had written this sketch of my pasture field, I called in a little school girl and read it to her. I wanted to hear her estimate of it.

"That's a nice story," she said; "but I don't want to study such things in school."

"And why not?" I asked.

"Because they are hard and dry," she said. Poor child! She was thinking of her books; and I remembered that I also had written books!

The heavens.

I would preach the sky; for the sky compels one to look upward.

When in the open country we are impressed most with the sense of room and with the sky. 


\section{The Commonplace}

City persons have no sky, but only fragments of a leaky roof; for the city is one structure and needs only a cover to make it a single building. They have no free horizon line, no including circle laid on the earth, no welkin. There are no clouds, - only an undefined something that portends rain or hides the sun.

One must have free vision if he is to know the sky. He must see the clouds sweep across the firmament, changing and dissolving as they go. He must look deep into the zenith, beyond the highest cirrus. We have almost lost the habit of looking up :

" Look unto the heavens, and see ;

And behold the skies, which are higher than thou."

Lie on your back in some quiet spot, and let yourself go out into the endless distances.

Or, if we note the sky, it is chiefly a midday or sunset recognition. Our literature is rich in sunsets, but relatively poor in sunrises. Civilization has led us away from the morning, and at the same time it has led us away from youthfulness. We have telescoped the day 


\section{Outlook to Nature}

far into the night, and morning is becoming obsolete. I know that this cannot be helped; but it can be mentioned.

I have asked person after person whether he ever saw the sun rise. The large number have said no; and most of those who had seen the sun rise had seen it against their will and remembered it with a sense of weariness. Here, again, our farm boy has the advantage: he leads something like a natural life. I doubt whether a man can be a poet if he has not known the sunrise.

The sky is the one part of the environment that is beyond our reach. We cannot change it; we cannot despoil it; we cannot paint signs on it. The sky is forever new and young; the seasons come out of it; the winds blow out of it ; the weather is born from it:

" Hast thou entered the treasuries of the snow, Or hast thou seen the treasuries of the hail ?"

The high places.

I preach the mountains, and everything that is taller than a man. 


\section{The Commonplace}

Yet it is to be feared that many persons see too many mountains and too many great landscapes, and that the "seeing" of nature becomes a business as redundant and wearisome as other affairs. One who lives on the mountains does not know how high they are. Let us have one inspiration that lifts us clear of ourselves: this is better than to see so many mountains that we remember only their names.

The best objects that you can see are those in your own realm; but your own realm becomes larger and means more for the sight of something beyond.

It is worth while to cherish the few objects and phenomena that have impressed us greatly, and it is well to recount them often, until they become part of us. One such phenomenon is idealized in my own memory. It was the sight of sunrise on Mt. Shasta, seen from the southeastern side from a point that was then untouched by travelers. From this point only the main dome of the mountain is seen. I had left the railway train at Upton's and had ridden on a flat-car over a lumber railroad some eight- 


\section{Outlook to Nature}

een miles to the southeast. From this destination, I drove far into the great forest, over volcano dust that floated through the woods like smoke as it was stirred up by our horses and wagon-wheels. I was a guest for the night in one of those luxurious lodges which true nature-lovers, wishing wholly to escape the affairs of cities, build in remote and inaccessible places. The lodge stood on a low promontory, around three sides of which a deep swift mountain ss;eam ran in wild tumult. Giant shafts of trees, such shafts as one sees only in the stupendous forests of the far West, shot straight into the sky from the very cornices of the house. It is always a marvel to the easterner how shafts of such extraordinary height could have been nourished by the very thin and narrow crowns that they bear. One always wonders, also, at the great distance the sap-water must carry its freight of mineral from root to leaf and its heavier freight from leaf to root.

We were up before the dawn. We made a pot of coffee, and the horses were ready, - fine mounts, accustomed to woods trails and hard 


\section{The Commonplace}

slopes. It was hardly light enough to enable us to pick our way. We were as two pygmies, so titanic was the forest. The trails led us up and up, under pitchy boughs becoming fragrant, over needle-strewn floors still heavy with darkness, disclosing glimpses now and then of gray light showing eastward between the boles. Suddenly the forest stopped, and we found ourselves on the crest of a great ridge: and sheer before us stood the great cone of Shasta, cold and gray and silent, floating on a sea of darkness from which even the highest tree crowns did not emerge. Scarcely had we spoken in the course of our ascent, and now words would be sacrilege. Almost automatically we dismounted, letting the reins fall over the horses' necks, and removed our hats. The horses stood, and dropped their heads. Uncovered, we sat ourselves on the dry leaves and waited.

It was the morning of the creation. Out of the pure stuff of nebulæ the cone had just been shaped and flung adrift until a world should be created on which it might rest. The gray light grew into white. Wrinkles and features grew 


\section{Outlook to Nature}

into the mountain. Gradually a ruddy light appeared in the east. Then a flash of red shot out of the horizon, struck on a point of the summit, and caught from crag to crag and snow to snow until the great mass was streaked and splashed with fire. Slowly the darkness settled away from its base; a tree emerged; a bird chirped; and the morning was born!

Now a great nether world began to rise up out of Chaos. Far hills rose first through rolling billows of mist. Then came wide forests of conifer. As the panorama arose, the mountain changed from red to gold. The stars had faded out and left the great mass to itself on the bosom of the rising world, - the mountain fully created now and stablished. Spriggy bushes and little leaves - little green-brown leaves and tender tufts of herbs - trembled out of the woods. The illimitable circle of the world stretched away and away, its edges still hung in the stuff from which it had just been fashioned. Then the forest awoke with calls of birds and the penetrating light, and the creation was complete. 


\section{The Commonplace}

The Conclusion of the Whole Matter

I have now reviewed some of the elements of the sympathetic attitude toward nature, and have tried to show how this outlook means greater efficiency, hopefulness, and repose.

I have no mind to be iconoclast, to try to tear down what has been built, or to advise any man to change his occupation or his walk in life. That would be impossible to accomplish, even were it desirable to advise. But even in the midst of all our eagerness and involvedness, it is still possible to open the mind toward nature, and it will sweeten and strengthen our lives. Nature is our environment, and we cannot escape it if we would. The problem of our life is not yonder: it is here.

The seeking of truth in fresh fields and for the love of it, is akin to the enthusiasm of youth. Men keep young by knowing nature. They also keep close to the essentials. One of the New Sayings of Jesus is this: "Raise the stone, and there thou shalt find me; cleave the wood, and there am I." 


\section{II}

\section{Country and City}

A RECENT press dispatch, reporting a A club dinner, asserts that the great universities of the future are to be in the great cities. There are no limitations, except physical ones, to the growth of metropolitan cities; in these cities the " universities will develop along special lines because of their special environment, and their development will be the best;" and "the scholar filled with the impulse of service is going to seek his home in the dark gray city, and seek to make it less dark and less gray." If a country university "wishes to study the fine arts, she has to divert funds to buy the objects of study," but the metropolitan university can turn to the galleries of the city.

In his address on "A Generation of Cornell," President Schurman used the following words : 


\section{Country and City}

"Not the noise and glare and rush of inane city streets, but the majestic calm and beauty of the face of nature is the proper place for the spiritual nurture of young men and maidens during the few short years devoted to the higher education. And fortunately there is no branch of learning or science, no sort of liberal culture, no species of professional training which cannot be more advantageously pursued in the country than in the city. It is not surprising, therefore, that Mr. Rashdall closed his great work on the History of Universities with the doubt 'whether the highest university ideal can be realized with the fullest perfection even in a single modern city of the largest type." "

Although these two strong utterances seem to be diametrically opposed, they are not at all surprising. They are the expressions of men who see great opportunities for useful service. That they see these opportunities just where they serve is the very proof that they serve well.

These antitheses are another illustration of the fact that the door of opportunity opens 
wherever men labor with ability and love, and that one's problems are just where he lives. Where the great universities of the future are to be is a matter of small consequence, if only they render great service to mankind, - for the universities are to reach out to all the affairs in which men engage, as well as to instruct those who come to their doors.

\section{Will the City dictate our Civilization?}

The question I propose now to discuss is whether civilization is to center only in the city. No one will dispute the great future that lies before the city. The imagination cannot picture it, as cities grow into stupendous aggregations of souls, with labor divided and subdivided, and human capabilities multiplied perhaps a hundredfold. The science of citybuilding is in its merest infancy, - men yet scarcely know what the phrase means. The human race is yet young. Famine and disease and war have held it in check; but these monsters we shall overcome. Where the earth now supports one human being, we expect, 


\section{Country and City}

before it die, that it will support hundreds. The cities will be the world's great nuclei, and, like all nuclei, they will be complex.

\section{The fundamental resources.}

But cities cannot build cities. The country builds the cities. The cities only handle and transform what the country produces. There are three great sources of raw material, — the sea and the mines and the soil. Some day the mines will fail; we shall transmute metals into metals and the dreams of the old alchemists will come true. The sea and the soil will remain while man lives on the earth. But men do not live on the sea: they only trade and travel there. The men who supply the cities will live outside the cities, in the open country.

\section{The rural people.}

The great metropolitan centers, even though they contain ten millions or fifty millions of people, probably cannot contain one-half the population of the earth. There will be cities of all lesser degrees, and villages, and quiet 


\section{$54 \quad$ Outlook to Nature}

hamlets, and rural communities, and isolated farmers, and poets living far out in the center of the world.

The men in the country are men, living their lives, with days full of work and of plans and of progress. They have problems, and these problems must be solved. These are problems of honest sustenance for themselves and those whom they love. The parasitic occupations are in the city. If the universities are to help to solve the problems of the "dark gray city," they must also help to solve the problems of the free open country. The city is elaborate and artificial : the country is direct and natural.

The country living is essentially an outlook to nature, and the farmer is a naturalist. In proportion as he is a good naturalist he is a good farmer. The farmer, woodsman, hunter, explorer, knows more about the things in the out-of-doors than you can find in any book, and he knows them so well that he cannot tell them. It is only those of us who acquire knowledge recently and freshly that hasten to publish it. The best naturalists do not write. 
The proportion of farming people.

The farmer has been counted out, or not counted at all, in much of the estimate of the world's progress. The educational and social forces touch him last or not at all, except as they demand his share for their support. I sometimes think that, as a race, our real outlook to nature is to rest largely on the farming occupation, and therefore that we need to conserve this occupation in order to recruit the native strength of our civilization as well as to provide a source of material supplies.

No doubt some of you are thinking of the enormous growth of cities and of the consequent lessening of the rural population, and draw the conclusion that we are to be a nation of cities, with agriculture playing a constantly less and less important part. It is true that relatively the country population is decreasing. The farmers are one-third or less of our people. I expect to see the percentage of rural population and of farmers fall still lower. What is to be the ultimate ratio of farmers to the total population in any self-sustaining geographical 


\section{$5^{6} \quad$ Outlook to Nature}

region it is not now possible to determine. But it is not so important to maintain a ratio as to see that the persons living on farms have the very best conditions for success; they will then contribute their necessary part to civilization.

It must not be supposed, however, that a lessening ratio of population means a depreciating agriculture ; in fact it may mean just the reverse, - that the persons remaining on the farm are increasing in efficiency. We are now an exporting nation, the exports of agricultural products greatly exceeding the imports; but most of the southern and many of the western states are still overwhelmingly rural; hence there is still reason and opportunity for persons to remove from the farms to the city. I am glad that so many of the farm boys have gone to the cities, for the cities need them; yet we must not suppose that all of them are going to the city.

The open country is essential.

It has been argued that since agriculture is concerned in the production of food, it cannot 


\section{Country and City}

be greatly extended, as the rise of civilization does not cause men to eat more. These arguments rest on the assumption that agriculture produces only or chiefly food; but probably more than half of the agricultural product of the United States is not food. It is cotton, flax, hemp, wool, hides, timber, tobacco, dyes, drugs, flowers, ornamental trees and plants, horses, pet and fancy stock, and a hundred other non-edible commodities.

The total food products in the United States, according to the twelfth census, was $\$ 1,837,000,000$. The cost of materials used in the three industries of textile, lumber, and leather manufactures alone was $\$ 1,851,000,000$. If the outlay for subsistence relatively diminishes as income increases, we must remember that the amenities and luxuries increase in intimate ratio with the income; and the larger part of these categories come from the farms and the forests. Mention but four agricultural articles - wood, paper, leather, cloth - that enter into our items of building, furniture, and clothing, and you see at once what civilization 


\section{$5^{8} \quad$ Outlook to Nature}

owes to the farm beyond what it eats. President Roosevelt has recently said with great force that the demand for wood is increased even with all the increase in fire-proof construction of buildings, because the amount of building is increased.

Compounded foods.

Perhaps some of you are dreaming of the days of chemical synthesis, when the laboratory shall make the foodstuffs and the day of the farm will be done. That day, however, will never come. The chemist may synthesize starch, but he will never make a potato. $\mathrm{He}$ will never make a leaf of lettuce, or a hen's egg, or an apple with its clean and fragrant juices, or food for a cow, or a fiber of cotton, or a flower that has breath from the wind and color from the sky. He will never make a seed that will know whether to grow into a turnip or a cauliflower or a cabbage. He may make food that will sustain life, but we shall never be content merely to feed, and, above all, to feed on tablets, - for it is to be hoped 


\section{Country and City}

that the day of pills and capsules is behind us, not ahead of us. And even if he should make the food, the city cannot supply him with the raw materials wherewith to make it.

The city lives on the country.

The city is dependent, and this dependency should be recognized in a rapid city-building age. The country problem is the city man's problem. No man who is far-sighted can shut himself up to city or country alone, for what makes for the ultimate good of one makes also for the good of the other; and it is to the city man's interest to see that the city exerts a salutary influence on the country.

Cut off the traffic in milk and water and other supplies from the country for twenty-four hours, and Boston will be in despair. Your shops and theaters will close; your trolley-cars will stop; your children will cry in distress.

Annihilate the cities and the country still exists; and I should not much marvel if it would be a month before some of the countrymen would hear of the phenomenon. 
60

The country is making progress.

The country is beginning to make very remarkable progress. This progress is not expressed so much in so-called "improvements" as it is in the city, but it is none the less permanent and real. The city is an advertising organism; but there are no signs in the country, unless placed there for city concerns.

The rural progress consists in a really marvelous development of machinery; a still more marvelous, extension of fundamental knowledge of the principles and practices of good farming; in the rise of social and economic organization; in the spread of sources and means of intelligence.

Resiliency of the West.

Much of this great change has developed in the West or has been stimulated by the West. Persons cut loose from traditions when they left the old homes and roamed over the vast areas of the new country. There was bigness in the stretch of the plain, freshness in the forest and prairie, generousness in the soil. 


\section{Country and City}

Vast areas of virgin land and small amount of labor called for, new and large methods. The lands soon paid for themselves, and surplus accumulated. This surplus has been turned into the home and the school. In most of the small towns of the prosperous parts of the West, the school building is the most imposing structure in the place. Freer ideas of farming developed, and larger ideas of the individual farmer and the home life.

These ideals are now reacting on the East. The East is arousing; and with the best of its traditions still preserved, it will again develop a race of mighty farmers, if, in fact, it has lost them. The so-called abandonment of farms of New England and other parts of the East is to be the salvation of the agriculture, for it means the abandonment of old ideas and the readjustment of the business into new lines. The great agriculture will be East as well as West.

The open country has its own society.

Not nearly all of mankind will go to the cities, and not all of the civilization and the 
progress of the race will be represented by the city. Not all the best character-building is to be in the city or even in the suburbs of the city. It is the city that breeds or attracts most of the crime. The country has its own life; it will have a better and more hopeful life, sweet, sane, moderate, and warm-hearted.

There are "homes" maintained for sailors and soldiers and actors, and others. Where is the "home" designed for farmers? Each farmer builds his own: it is the first thing he does. The farmer does not think of renting a house to live in, unless he is a mere tenant. Let Congress or any legislature propose to establish a "home" for farmers, and it insults every farmer in the land. The farm idea is the home idea. The farmer is practically the only person who makes his home, lives in it, and passes it down to his children. Homes go with land, not with franchises.

The farmer holds his ground, sometimes even too tenaciously. The struggle may be hard and the odds against him, but day in and day out, year in and year out, sun and rain, 


\section{Country and City}

he stands by the plow and works out his own salvation. I hope that new schools and better social forces will touch him into quickened life; but I hope also that he will always be conservative, for an enlightened conservatism is the safeguard of society.

The country school and college.

Moreover, the countryman will not always go to the city to be taught. It is only recently that he has gone to the city. Once the country school and the country church were as good as any. Cities have grown, and the country has stood still. It is now time for the tide to turn. We shall consolidate and centralize our schools, or otherwise intensify them, and have as good schools in the country as in the city. Perhaps they will be better by being smaller and simpler.

I look for the time when city children will be sent to the country to school. The farm boy and the farm girl are not going to the city to college unless they expect to leave the farm; they may not go there even then. The 


\section{Outlook to Nature}

city is not their realm; and men are to be taught in their own realms.

We shall have more colleges and universities rather than fewer; these institutions will serve mankind; they will be where the problems of mankind are; some will be in metropolitan cities and some in cities of lesser estate; some of them will be rural; a college will not necessarily be useful in proportion as it is bulky; methods and ideas associated with colleges will probably crystallize around new foci, and what is now considered to be central may some day be considered as peripheral. Very likely we shall see again the rise of the individual, unattached, and isolated teacher, who shall cut himself free from all cults and systems and take his followers directly out to nature.

The city galleries and collections.

The extract that I quoted pleads the value of collections and galleries. But "collections" are only incidents in any educational scheme. We have made the mistake of considering them to be of first importance. 


\section{Country and City}

We are in the era of making great libraries: perhaps the time will come when we shall think more of dispersing books than merely of collecting them. Perhaps it will be better to have one thousand books with one hundred families than ten thousand books in one library. The library should be a home idea as well as a collection idea.

The old idea of the natural history museum was for persons to "see." It was largely an exclamatory institution. It is now supplemented by specimens to work with; and specimens to work with are being related to the fields where their places are. Dead things alone are for dead teachers. The museum and collection idea is necessary, but it is still largely an exhibition idea.

I brought a live bittern to my house; the children left their books to watch it. The bittern died and I had it stuffed and put it on the mantel; the children left the bittern for the books. I gave the bittern to the museum; it was not good enough for children. 
66

Outlook to Nature

The out-door galleries.

Is it not strange that all our art galleries are indoors? We get up at ten o'clock in the morning and call a carriage to drive us to the gallery to see a picture of a sunrise! We must see a picture of a tree before we are aware that a tree is worth making a picture of. Yet the world out-of-doors is the real source of art and the real gallery; all our best galleries and best buildings are but adaptations, imitations, and interpretations.

Collections and galleries by means of which to teach men? They are trivial compared with what I can show you in yonder fields. Collections instruct those who would be instructed; we need many more of them: but my fields have intrinsic uplift and inspiration. The art gallery and city cannot have real fields, and real forests, and real animals, and real live-stock, and real landscape.

Some day we shall construct great pictures out-of-doors. We shall assemble the houses, control the architecture, arrange the trees and the forests, direct the roads and fences, display 
the slopes of the hills, lay out the farms, remove every feature that offends a sensitive eye; and persons will leave the galleries, with their limitations and imitations, to go to the country to see some of the greatest works of art that man can assemble and produce. These works will have sweep and breadth and distance. They will compromise whole countrysides. Every rain and wind and snow will heighten their efficiency and their meaning. Many of the works that we are so fond of indoors will appear trivial and vain.

Any artist may profit by the remark of Frederick Law Olmsted, then a young man, on visiting Eaton Hall: "What artist, so noble, has often been my thought, as he, who with farreaching conception of beauty and designing power, sketches the outline, writes the colors, and directs the shadows of a picture so great that Nature shall be employed upon it for generations, before the work he has arranged for her shall realize his intentions."

Art societies will be formed whose attention will be given chiefly to art out-of-doors. A 
new art profession is just now rising, having for its sphere the real fields under the open sky. As yet it has no name. Once it was called landscape gardening, when its efforts were confined to the constricted areas of gardens and parks. Now it is called landscape architecture, as in its present stage it has much to do with buildings and engineering problems. Soon it will rise beyond all these arbitrary bounds and take the face of the earth for its own. Even now, we know that the regulation of the scenery of mountains is not too large for its grasp.

\section{Countryman and City Man}

I am speaking to city people. This leads me to say that there are two kinds of country and of country life, - the country of the city man and the country of the countryman. These prospects are wholly unlike, for the country is seen from opposite points of view, and with different preconceived ideas.

The city man looks outward to the country : it is his respite and release. The countryman 


\section{Country and City}

is part of the country: it is his realm and his support. The city man thinks chiefly of agreeable features of the country; he is interested in its beauty and novelty and in its contrasts with the city. The countryman does not think of the features, for all features are his; he escapes neither weather nor season, since he belongs to the country as much as the trees and fields belong to it.

The attitude of the city man is, "Come, let us go into the fields." The attitude of the countryman is, "These are the fields; here am I." Keats well expresses many city men's attitude :

“ To one who has been long in city pent,

' $T$ is very sweet to look into the fair

And open face of heaven, - to breathe a prayer Full in the smile of the blue firmament.

Who is more happy, when, with heart's content,

Fatigued he sinks into some pleasant lair

Of wavy grass, and reads a debonair And gentle tale of love and languishment?"

The farmer's attitude may be expressed somewhat as follows: 
I hoe and I plow

I plow and I hoe

And the wind drives over the main.

I mow and I plant

I plant and I mow

While the sun burns hot on the plain.

I sow and I reap

I reap and I sow

And I gather the wind with the grain.

I go and I come

I come and I go

In the calm and the storm and the rain.

Two points of view.

Our point of view is determined chiefly by the means that brings us support: the city man, even though he lives in the country and loves it, is supported by the city. He thinks as the city thinks. $\mathrm{He}$ often has a feeling of pity for the man who must live always in the country. $\mathrm{He}$ is urban-minded.

The countryman has his own peculiar mental processes and points of view. The city is little to him except as it buys his products. His interest in the news columns of the news- 


\section{Country and City}

paper is of a very different order from that of the city man. He is not a sportsman, - he seldom hunts for the "sport" of hunting. You know the genuine countryman when he comes to town; but he cares little what you think of him. He has a deep-seated dislike of the city. $\mathrm{He}$ considers that his is the original estate; and it is significant that the dictionaries recognize the unit word "countryman" but no corresponding word "cityman." $\mathrm{He}$ is rural-minded.

As the city man's point of view of the country is essentially a civic idea, it is clearly outside my province to discuss the larger relations of it. The city man's country life is of two kinds, - vacationing and summering in the country, and the making of homes in the suburbs. These interests are now well represented by magazines, but so far the original country life is represented only by the agricultural class periodicals. It is not my purpose to discuss the vacationing and summering in the country, for that is largely of temporary and secondary importance. I am 
more interested in the permanent home-making force of country life.

The sub-urban.

The home idea is clearly dying out in the cities. Homes seem to be incompatible .with compact city life ; consequence is that the serious-minded middle class is constantly working out and out toward the suburbs and the adjacent towns, in the effort to secure the greatest possible proximity to nature consistent with business prudence. This transfer of domicile at once raises farreaching questions. The political philosopher sees danger because this movement removes a large class of voters and is likely to leave the city, or the congested parts of it, in the hands of politicians. The social philosopher finds a new breed of citizen developing, - not countrybred nor city-bred, but suburban-bred, product of neither extreme. Will this citizen have the prejudices of either extreme? And will he be a more useful social factor because of his intermediate origin? 


\section{Country and City}

The city obligation.

The country is certain to exercise a profound influence on the city. We now know that the city, with all its wealth of attractions and its suggestions of luxury, leaves some of the highest aspirations unsatisfied. The very intensity of the city demands the country as an antidote and corrective.

On the other hand, the city is to have a most marked influence on the country. The country needs the city. It does not need the city man so much to teach the countryman farming, as to touch and elevate the general currents of all country life. The city man goes to the country with new and large ideas, active touch with great affairs, keen business and executive ability, generosity, altruism, high culture. May we not hope that he will also always go with sympathy? All these traits will arouse the country from its tendency to complacency and narrowness. The blend should perhaps produce the real American. Certainly the city has a distinct duty to perform toward its contributory country, to help to build it up rather than 


\section{Outlook to Nature}

to drain it, - a duty as clear-cut and imperative as any of its customary unselfish and highminded efforts in aid of the world's progress; and it is gratifying to know that even purely agricultural questions are now arousing unusual interest among city people, as one part of the great volume of human affairs. The problems of the open country constitute an important part of the problems of civilization.

\section{The Garden}

It is my purpose, however, to speak of the personal and domestic influences of the country, rather than of public policies; and I have just been speaking of the suburban kind of country life. You go to the suburbs and the country in order that you may have more room, less racket, better health, more freedom, and closer relations with sun and wind and sky. But there should be more than a home in the country, - there should be country in the home. One room of the home should be an epitome of the country, as essential as dining-room or "den." 


\section{Country and City}

By the way, the development of the "den" as a part of a modern house is most significant: it is a protest against the "spare room" and all meaningless conventionality and unnaturalness.

\section{The garden room.}

The room of which I am thinking is commonly known as a garden. I am not now considering so much the landscape part of the place, with its plan of lawn and trees and borders: this is a part of the general architecture of the establishment, a kind of foundation on which the builded building rests. The landscape garden will naturally comport with the style and "feeling" of the architecture of the place as a whole, - secluded if the house is secluded, bold, or homelike. Too often, I fear, the American yard is likely to resemble the literature of the period, in being striking, curious, or wonderful. Often it is of the lookat-me kind, made to be stared at, as a street sign, resplendent in its paint, is to be stared at.

It is not the "front yard" or the "spare room" that gives the real character to the 


\section{Outlook to Nature}

home. You will see an English country home of very modest appearance; you may think it dull or uninteresting, yet somewhere behind the house or against the wall you are almost sure to find a garden, as secluded and as personal and individual as a library or a study. I wish that Americans would make gardens even if there were no hope that people would see them.

The meaning of home has broadened and deepened very much within a lifetime. To the plainest home of the middle class there have been added a few good pieces of simple and useful furniture, a little collection of 'books good at least to look at, simple music, pictures that have some meaning and are not mere wall decorations : may we not now add a garden? It does not matter how small or how large the garden is. If it is small, it will be condensed and perhaps we shall appreciate it the more.

The spirit of the garden.

I step from the house, and at once I am released. I am in a new realm. This realm has 


\section{Country and City}

just been created, and created for me. I give myself over to the blue vault of the sky; or if it rain, to first-hand relationship with the elements, - for can I not touch the drops that fall from some mysterious height? I am conscious of a quick smell of the soil, something like the smell of the sea. I hear the call of a bird or a faint rush of wind, or catch a shadow that passes and is gone. There is a sudden sensation of green things tumbled over the ground. I feel that they are living, growing, aspiring, sensitive.

Then the details begin to grow up out of the area, every detail perfect in its way, every one individual, yet all harmonious. The late rain compacted the earth; but here are little grooves and cuts made by tiny rills that ran down the furrows and around the stems of the plants, coalescing and growing as they ran, digging gorges between mountainous clods, spreading into islanded lakelets, depositing deltas, and then plunging headlong toward some far-off sea, - a panorama that needs only to be magnified to make those systems of 


\section{Outlook to Nature}

rivers and plains and mountains the names of which I sought so much in my old geography days.

Soft green things push up out of the earth, growing by some sweet alchemy that I cannot understand but that I can feel. Green leaves expand to the sun; buds burst into flowers; flowers change to fruits; the pods burst, and berries wither and fall; the seeds drop and are lost, - yet I know that nature the gardener will recover them in due season.

Strange plants that I did not want are growing here and there, and now I find that they are as good as the rest, for they spring from the same earth yet are unlike all others, they struggle for place and light, and they too will have their day and will die away and in some mysterious process will come again. Insects crawl here and there, coming from strange crevices and all of them intent. Earthworms heave their burrows. All these, too, pass on and die and will come again. A bird darts in and captures a flying insect; a dog trots across the farther end of the plot; a cat is hidden under 


\section{Country and City}

the vines by the wall. A toad dozes under a bench: he will come out to-night.

It is all a drama, intense, complex, ever moving, always dying, always re-born. I see a thousand actors moving in and out, always going, always coming. I am part of the drama; I break the earth; I destroy this plant and that, as if I were the arbiter of life and death. I sow the seed. I see the tender things come up and I feel as if I had created something new and fine, that had not been seen on the earth before; and I have a new joy as deep and as intangible as the joy of religion.

\section{The Outlook for the Country}

If a careful outlook to nature is much to be desired, and if farming occupations are the nature-occupations, then it follows that the condition of farm life is of much concern to every person who recognizes his responsibilities in the world.

The country must hold its place in society through an elevation of its ideals, and this can come about only by means of education. There 
is now a shifting of emphasis in agriculture teaching from the crop to the home. The burden of teaching has been chiefly to make the farm more productive. This is fundamental, and these efforts will not be remitted; but the farmer is a man and a citizen as well as a producer. $\mathrm{He}$ must be instructed in matters pertaining to good schools, good churches, good roads, good local government, good politics; he must be stimulated in citizenship; and his intellectual and spiritual horizon must be broad enough to allow a sympathetic appreciation of the nature of which he is a part.

Rural economics and rural sociology are subjects now announced in college curricula. Even college people are asking what these subjects mean, thereby admitting that they have considered humane subjects to appertain only to cities and other assembled interests. In the coming generation, the teacher in social and economic questions will exert a greater influence on the elevation of country life than the teacher of technical agriculture. 
The country home.

The farm home is the most direct and simple home; it is least disturbed by passing moods; it is nearest nature. It is important to the nation that it be preserved; but it is also important that it be improved.

The first thing I would now do for the farm home is to put in sanitary water-works, for the care and comfort of the person. Nothing would so soon elevate the home ideals.

Then I should try to reorganize the woman's work, as much as the man's work has been reorganized in the barns and on the fields.

Next, I should revamp the lay-out of the home grounds, to make them convenient, neat, attractive, even artistic.

Then I should want to consider the reading, - not too many newspapers, but books and bulletins and some magazines, the reading of which would increase knowledge and direct the development of good taste.

Millinery architecture.

Then I should improve the architecture. 
Buildings are silent teachers; every hour their impressions are repeated.

I often wonder how it is possible for human beings to construct such homely dwelling-places as they customarily build. Consider the looks of the buildings that you see, one after another, along any street: birds and beasts do far better. The architects are partly to blame for lack of good taste and good sense in farm buildings, because they have concerned themselves so exclusively with ambitious structures that common people do not think of common buildings as having any "architecture." Most persons do not know that good architecture is more a matter of proportions than of ornaments and accessories. For several years I have tried in vain to find architects to give advice on ordinary farm buildings. If I found any who would consider the question, they had in mind such buildings as only a city farmer could afford to build. Every building, even though it cost only five dollars, is either good architecture or bad architecture. Usually the most expensive dwellings are the most showy and formless. 
A century ago farmhouses were mostly direct and tasteful in mass effect. We yet admire these old well-proportioned buildings, notwithstanding all their imperfections of plan. Then came the great development of cities, and with it the rise of millinery architecture. The country copied; and we now see the effects, narrow-chested gawky buildings standing high in the air as if land were worth so much a square foot, with jig-saw cornices, ten-pin gables, and chicken-legged porches.

\section{The need of social association.}

There is education in assembling with one's fellows. This is why city populations are so alert. Rural families are scattered. In some way, the deadening effect of too complete isolation must be overcome. It will not be overcome by farmers assembling in hamlets. The life of the ordinary hamlet is likely to be of a lower type than the life of separated farms.

There is every indication that we are coming to at least a temporary halt in the rural unrest. 


\section{Outlook to Nature}

We shall expect, therefore, that new centers of social crystallization will develop. Perhaps a recrudescence of the rural school will make it again something like a social center. In parts of New York and New England, the grange hall is rapidly supplying this necessity. In some places the church will meet this need; in other places, the rural library; and increasingly will special community halls be erected.

All constructive agencies will make for social cohesion by arousing a keener desire for it; but I doubt whether this cohesion will result in real village life so much as in the development of a social farm life.

Reading for resource.

The countryman will always be comparatively isolated, but this need not mean that the country is to be characterized by intellectual poverty. The farmer needs literature, - literature that is bright, true, and relevant. Most of the books that he reads - as also most of those that his children study - are made for towns-people. 


\section{Country and City}

Where is the fiction that portrays the farmer without overdrawing or caricaturing him? Where are the candid and interesting farm sketches? The farm poems? The writing that will do for the farm what has been done to interest persons in nature?

A good technical agricultural literature is now developing, and this is certain to be followed by a new range of artistic writing. It is astonishing how utterly agricultural experience has been neglected in literature. Great movements have come and gone, ideas of wide sweep have risen and passed away, unconscious experiments of continental area have been made, industries have developed and have disappeared, discussions on burning questions have caught from schoolhouse to schoolhouse, customs have died out, inventions have been forgotten, systems of farming have been outlived, books have been written to be stored in old attics, strong men have lived and died, and yet all these treasures of human experience are unknown to the writers and the historians.

I never look over my shelves of old agricul- 
tural books that I do not feel sure that some day an attractive literature will rise out of the achievements of these neglected rural people. This literature will have a large significance because it will utilize genuine material that has accumulated slowly and naturally and in great part without conscious purpose, and which, therefore, lies very close to original feelings and motives of men.

\section{The nature-ward tendency.}

A fundamental offset for isolation is the development of a keen intellectual and spiritual interest in the objects and affairs of the country. The nature-study movement - to use the phrase in its broadest sense - is now evolving this insight. A sympathetic knowledge of nature will in the end be more satisfying than much of the amusement that the town has to offer.

This sensitiveness to nature is now developing very rapidly also in the towns, and many towns-people are expecting to take up farming largely to satisfy this desire. I fear that many 
of these persons will be disappointed, not because they will fail to find the interest in nature but because they will know nothing about farming and the practical affairs of the country; and no doubt some of them will find the love for the town to be deeper-seated than they had been aware.

The farmer himself will develop this naturelove slowly and non-theoretically, and it will abide; at the same time, his occupation will be developing out of mere laboriousness, and he will have some strength and opportunity remaining for the enjoyment of his environment. I am sometimes told, when I make remarks similar to these, that I am idealizing. I hope that I am, for if farm life cannot be idealized, it cannot be recommended; but $I$ hope that the ideals are attainable.

\section{The reverential attitude.}

The countryman's training, whether in home or school, should be such as to intensify his spiritual reactions. There is danger that we miss the reverential attitude toward life. 
The reverential attitude is the result of our feeling toward the materials of life, - toward the little things and the common things that meet us hour by hour. One stimulates it in himself only as he feels that the earth is holy and that all the things that come out of the earth are holy. A man may conquer the earth and yet feel that he has taken no advantage that does not belong to him because he is a man, and may hold the highest reverence for the rights and welfare of everything that exists. Such an attitude of mind as inclines one to pause to listen to a bird's song (even though he may not stop his work), to give more than a passing glance to a potato plant, to inhale some deeper draught of the fragrance of new-plowed land, will produce in him a sweet seriousness that will stand him in good stead in stress and strain, and will much reinforce his spiritual stability.

The point of attack.

If these remarks mean anything, it is that we need new country institutions developed from 
the country point of view, not merely city and town institutions transplanted to the country. City persons who desire to "reform" the country are very likely to forget all this and to begin with schemes of social or economic organization. All schemes must begin with the individual farmer. The country youth must not only know more, but he must have a country mind in the broadest sense.

\section{The poetical farmer.}

I am always interested in Thoreau's " poetical farmer," not because I recommend his kind of farming, but because of his philosophical point of view: "Minott is perhaps the most poetical farmer, the one who most realizes to me the poetry of the farmer's life, that I know. He does nothing with haste and drudgery, but everything as if he loved it. He makes the most of his labor, and takes infinite satisfaction in every part of it. $\mathrm{He}$ is not looking forward to the sale of his crops, but he is paid by the constant satisfaction which his labor yields him. $\mathrm{He}$ has not too much land to trouble him, too 
much work to do, no hired man nor boy, but simply to amuse himself and live. He carcs not so much to raise a large crop as to do his work well. He knows every pin and nail in his barn. If any part of it is to be floored, he lets no hired man rob him of that amusement, but he goes slowly to the woods, and at his leisure selects a pitch pine tree, cuts it, and hauls it or gets it hauled to the mill; and so he knows the history of his barn floor. Farming is an amusement which has lasted him longer than gunning or fishing. $\mathrm{He}$ is never in a hurry to get his garden planted, and yet it is always planted soon enough, and none in the town is kept so beautifully clean. He always prophesies a failure of his crops, and yet is satisfied with what he gets. His barn floor is fastened down with oak pins, and he prefers them to iron spikes, which he says will rust and give way. He handles and amuses himself with every ear of his corn crop as much as a child with its playthings, and so his small crop goes a great way. He might well cry if it were carried to market. The seed of weeds 


\section{Country and City}

is no longer in his soil. He loves to walk in a swamp in windy weather, and hear the wind groan through the pines. He indulges in no luxury of food, or dress, or furniture, yet he is not penurious, but merely simple. If his sister dies before him, he may have to go to the almshouse in his old age, yet he is not poor, for he does not want riches."

\section{We need the Country}

Therefore I preach the open country, because it is natural and without affectation.

I preach the plain and frugal living of plain people. Yesterday the bill of fare that was put before me at my hotel contained, by actual count, the names of 567 articles. To judge by the names, most of them were inedible. Ten articles are sufficient, and twenty are luxury.

I preach the steadiness of country life, its freedom from speculativeness and from great temptation to evil doing. We need the example of all simple and direct lives, even if we lose some of the "polished" manners. We 
need the freshness and the spontaneity, and the power to rely on one-self. The day of homespun is past, and the day of the machine has come: danger is that the machine and the formal affairs shall come between us and the essentials. We are too likely to work by proxy and through servants.

\section{We need the example of simple institutions.}

With the increasing complexities of civilization, it may be impossible to simplify the machinery of our political life; yet we all have the desire to do so, and we feel that the more direct the institutions the more efficient and enduring they are. The simple native institutions have largely determined the methods and points of view in great geographical regions; - the New England town meeting, with its ideal democracy; the southern court-house, with its social stratification; the central-west schoolhouse, repeating the democracy of New England but with a freer individualism; the arid-west ditch meeting, repeating again the democracy, 
but made applicable by the urgency of a single vital problem. It is doubtful whether a nation of cities could be a democracy.

Not all the people should live on salary.

I think that we need the example and influence of men who do not live on salary. One reason why boys leave the farm is because in other occupations they are offered wages or salary, and the risk of livelihood is thereby reduced; but the very lessening of this risk sacrifices much of a man's self-reliance, - it loses him his independence, not only in directly securing the means of support, but, what is more serious, in his attitude toward society.

Salary-practice is a concomitant of organization, and it goes with social stratification. The man who receives salary exclusively depends on some one else, and his opinions are controlled, or at least modified, thereby. Often to a very large extent he loses his autonomy. There is a general feeling among salaried men that they must engage in 


\section{4 \\ Outlook to Nature}

other business in unsalaried hours, not always so much, I think, because they desire to add to their income, as to satisfy the longing for some greater measure of independence.

The farmer is about the only man left who lives directly on his own efforts, without the aid of salary, speculation, or the non-intrinsic profits that accrue from trade. There is a tendency to organize agriculture, and thereby to develop salaries in it; this tendency is no doubt to be commended, yet I look with some apprehension to the effect that it may have on independent effort and opinion.

We need the out-of-doors.

Certainly all our people need the open air and the example of contact with freedom, and the practice of good unconventionality.

A matron of a large boarding-school for girls told me recently that many of the pupils come to her so thinly clad that she is obliged to keep her houses too warm for health in order to make the girls comfortable. This school is an expensive one and the girls come from well- 
to-do families; it is not a question of expense : the matron said that by many mothers it is not considered "good form" for girls to dress warm. The girls are clad in gauzy shivery stuff, and they therefore become hothouse subjects, withdrawing from the cold and discomforted by every change of temperature.

We magnify the comfort of living indoors. We have made the inside of the house so attractive and so suggestive of ease that the temptation is to go outside as little as possible, as if the out-of-doors is to be avoided. We have so many books even about the outof-doors that we do not need to go out-of-doors to learn about it.

Americans are fond of saying that the Europeans have been far behind us in developing the physical comforts of the home. I also am proud of this; but I sometimes wonder whether this is not due in part to our dread of the out-of-doors, and whether this very physical perfection of the house may not still further emphasize the breach that has grown up between ourselves and nature. There is, to be 
sure, a tendency in American house-building toward an outdoor feeling, but this usually does not extend beyond the veranda, which is really built for protection. The sedentary indoor life has its sure effects, and we try to correct these effects by means of drugs; and the American is known by his nostrums.

A new and strong kind of nativeness is no doubt developing in the cities; but we also need the kind of nativeness and homefulness that develops in the country. I am always conscious that there is no soil in the city, but only dirt; the ground must be covered until it is blotted out. When we get away from the soil we begin to get away from simplicity and directness.

We all perceive a growing tendency countryward, coming in response to a universal soulhunger that the strenuous and complex life does not fully satisfy. Sooner or later, most men come to feel as did the city schoolboy who declared that some day he would live in the real country and would build his house out-of-doors. 


\section{III}

The School of the Future

$7 \mathrm{HE}$ pupils in a certain school were asked

1 whether they could define or distinguish an educated man. After a long pause, one little girl raised her hand and said that she surely could tell. "An educated man," the child said, "is one that does not work."

This homely reply admirably illustrates a popular conception of education, - that it does not put one into direct relation with the affairs of life, as if education and occupation are incompatible.

Most of us will not accept the child's opinion; yet there seems to be a deep-rooted feeling that a person cannot be really educated by means of subjects that have a direct application to the common necessities of living. It was an old idea that education makes a man accomplished. 
It is the new idea that it also makes him useful; and as all spiritual progress is inseparably associated with physical welfare, this new education stands for the completer and the larger man.

I have always liked the story of the Adirondack guide, who thought Agassiz an educated man and Lowell an ignorant man, for it is a forcible expression of the fact that there is more than one kind of education, - Agassiz knew the things that appealed to the guide.

\section{Education for "culture."}

It is still asserted that some education leads to "culture." This I have no desire to dispute, but I do not like the inference that other education does not lead to culture. This question cannot be closely discussed unless one defines what he means by "culture." Much of what passes as culture is very superficial attainment and may be little more than good manners. But breadth of view, clear reasoning power, good judgment, tolerance, high ideals, sensitiveness to art and nature, devotion to 
service, - these are of the greatest value, and they may be the result of more than one line of educational effort. The old-time formal and literary attitude, with facility in a particular group of academic subjects, is much to be prized; but sensitiveness to life is the highest product of education.

I read recently in a college paper that " the classics are the source of culture, all culture, and they always have been"; and again: " Greek, once considered the foundation of all culture, is fast dying out, and our whole system of education for the sake of culture and power is threatened with destruction by the everincreasing flood of materialism in scientific courses, and of practicalism in the professional courses. The task of stemming this flood has given rise to the most vital and difficult problems of the modern university." I wish that we had more Greek, but I do not admit that Greek or any other group of subjects is the sole source of what we ought to know as "culture," nor that " materialism" is a result of scientific courses, nor that "practicalism" 
is any bar to the highest flights of thought; and it is strange that any person in these days should regard Greek as the one preëminent source of power. All education should lead to culture and to power.

\section{Education for power.}

How can a man's mind be trained? It can be trained by being employed in some definite, integrating, and consecutive effort. It matters little what the subject-matter is: if the mind is employed effectively, it will be able to make a still more effective effort. Many of the old subjects train the memory chiefly and their results are superficial.

"Reasoning power" develops by use. This power ought to be as effectively used by reasoning from problem to solution in biology or physics or agriculture or engineering as in formal philosophy and logic. A man can be trained to think just as accurately by means even of agricultural subjects as by conventional subjects, provided the agricultural subjects are as well systematized and equally well taught. 
No one subject can have the monopoly of learning, unless we wish to restrict education.

The theory of the choice of subjects is now well established, but we still need to liberalize the teachers and the schools. The difference between "technical" and "cultural" education is essentially one of intention rather than of subject.

Application to life.

If one subject may be as effective as another in training the mind, it will naturally be asked why it is necessary to introduce the new subjects at all, inasmuch as the old are already well established. The answer is that the mere "training" of the mind is not the only purpose of education, but that education should make the man efficient and useful. It should put him into sympathy with common affairs and the questions of the work-a-day world, and it should give him usable information. Education should have a tendency toward something definite; for the educated man, if he is to help and lead the world, must not stand above and 
aloof from mankind. When only Greekminded men went to college, it was enough that Greek was taught; but now that physicsminded and physiology-minded and farmminded men go to college, engineering and physiology and agriculture also should be taught. I do not suppose that there is any way whereby an examination of the fiber of an educated man's brain could reveal the means by which the mind was trained.

\section{Liberal education.}

It is a favorite assertion that some education is "liberal." So far as this word is merely a name to designate a certain group of subjects, no one can object; but if it is the inference that other subjects are illiberal, then the statement cannot go unchallenged. The fact is that the older type of education is likely not to have a liberalizing effect, because it not only confines a man's attention to certain efforts that may be narrow in themselves but often renders him unsympathetic toward those who have not pursued a similar course, and also toward affairs in 
general. I once heard the president of an excellent literary college say that his institution "educates men, not farmers and blacksmiths." Most persons now think that a college may educate farmers and blacksmiths to be men.

\section{The humanities.}

It is most curious that we should ever have considered the concerns of men to be unworthy of study until they had become centuries old and had been more or less imperfectly embalmed in tradition and literature. The most humanizing course of study is that which puts the man into closest sympathy with the activities and ideals of men in times past and in times present.

We ought to recognize the transcendent value of human experience as expressed in its religions, its history, its art, and its literature, and to make it the nucleating agency in the educational system; but it is just as fatal to the highest scholarship and to the best intellectual and spiritual development to have an education exclusively in what we are in the habit of calling the humanities as in what we 
call the sciences and the affairs: either is incomplete and one-sided, and cannot give a rounded and rational view of life, or put one into full sympathy with the achievements of the race. The humanities often develop the man unhumanly.

\section{The School of Affairs}

There are two kinds of schools, - the institutional school, and the school of affairs. Many an unschooled man has been well trained in the school of affairs. The untaught farm boy goes to the city and succeeds because he has learned certain things in the daily round of life that are of more value to him than all that he could learn from the books.

The ideal training would be the addition of the school work to the real work; but if either one is to be omitted, it should be the school. In the old days the school was a supplement to the home; now it tends to take the place of the home. In many cases the child now spends most of his time in school and in vacationing; and there is little opportunity for the develop- 


\section{The School of the Future}

ment of the strong native traits that were so pronounced in the old days. I would not have less schooling; but I would advise that the school supply what the home and the business can no longer give. No boy or girl should leave school without the power to attack a question in actual affairs or to do a piece of work with the hands. I do not consider a person lacking these powers to be well educated, even though he knows all the books.

The minister came to see me, and I showed him the garden and the barn. His eye caught the tool-bench. "What a fortunate man you are!" he said. "You can use tools; I cannot do a thing with my hands, except to play golf."

The school of farm affairs.

I shall now speak of some of the ways in which the school of affairs trains men, developing qualities and powers that are indispensable to a right life. I shall choose the case of the farm boy because I am most familiar with him and because his relationships are directly with 
nature, - and the theme of my lectures is the meaning of the outlook to nature.

In making these statements, I have no desire to glorify the farm boy or to magnify the advantages of farm life: I speak of some of the positive training processes of the farm only to show that the unschooled man may be in a very true sense an educated man, and to enable me thereafter to make some suggestions for the public schools themselves. Unlovely traits are often bred on the farm; but these faults are not necessarily inherent in farm life and they will be fewer in the future. Nor do I wish to be understood as implying that the farm-bred man is to be as indispensable to the city as he has been in the past. The city is now finding itself, and is developing strong men of its own; but even in the city many of the strong traits will also be developed in the school of affairs, for everywhere the business of life educates the individual.

(I) The farm boy's activities are direct. $\mathrm{He}$ deals with real, actual, essential things, problems, and events, and develops practical 


\section{The School of the Future}

knowledge and ability. He can "do" things. City boys are likely to deal with pictures and models and descriptions, and with made-up exercises. The farm boy must overcome his own difficulties for himself. Every day brings him a hundred of these natural problems. He tips over with a load of hay in the back lot. Does he go to the village to consult an expert or to the library to look up references?

$\mathrm{He}$ lives close to the raw materials, deals first-hand with them, and his methods, although sometimes primitive, are short and effective. I am impressed with the indirectness and expensiveness of much of the work in cities, - those who do public work especially seem usually to be killing time, and the methods by which they are employed seem to a countryman to be political and circuitous and to involve a great waste of efficiency.

(2) The farm boy is trained to be industrious. If he turns out to be lazy, he finds no system of political patronage to float him along. It is commonly thought by outsiders that the farm boy's life is hard. It is true that it is 
often harder than it need be; but in general it is hard only to those who shudder at the thought of work. Eight-hour men may think of it as hard. In Chicago, a short time ago, I was amused to see "laborers" roosting on the iron fenders in front of labor-bureau offices, where most entertaining signs were hanging around them and beneath them offering attractive work at high wages and with free transportation; it was apparent that the men were not looking for work, but for the job that had the least work in it.

The farm boy has little opportunity to choose the easy jobs. He is confronted by the entire situation, - the series of problems imposed by the seasons and the years. The farmcourse is complete in itself and its duties must all be met, without thought of escape; therefore, it is a system of natural discipline.

One of the great questions of the city is that of idleness, - one cannot see the floating youth on the streets without being impressed with this fact. The school hours often are reduced to a minimum, the child 
has no serviceable employment, and he drifts; the farm boy has his chores to do after school.

I cannot leave this subject without again denying the common notion that the farm boy's life is mere drudgery. Much of the work is laborious, and this it shares with all work that is productive; for the easier the job the '_is it is worth doing. But every piece of farm work is also an attempt to solve a problem, and therefore it should have its intellectual interest. It needs but the informing of the mind and the quickening of the imagination to raise any constructive and creative work above the level of drudgery. It is not mere dull work to follow the plow - I have followed it day after day - if one is conscious of all the myriad forces that are set at work by the breaking of the furrow; and there is always the landscape, the free fields, the clean soil, the rain, the promise of the crops. I cannot help wondering why it is that men will eagerly seek work in the grease and grime of a noisy factory, but will 
recoil at what they call the dirty work of the farm. So much are we yet bound by tradition!

(3) The life of the farm boy is varied. The farmer handles an entire business, not some small part of a business, and he is therefore able to lead something like a naturally rounded life. In an age of minute division of labor, this is important, for it tends to develop many abilities rather than to make a man a cog in a wheel.

I often hear it said that the farmer's life is munotonous. This is true only so far as it may confine his activities to one locality. $\mathrm{H}$ is work does not compare in monotony with that of the average workingman or the average business man; but other men may have more divertisement provided for them, - and for this the farmer will have time and desire when he comes to organize his effort and to develop a greater sensitiveness to his surroundings. To a large extent, he must provide his own diversion.

The farm work itself, while of the same general kind year by year, is endlessly varied in its details, and this is the very reason why 
the business is so difficult for the unresourceful man.

(4) The farm boy's life is simple. Usually he has only the essentials. No doubt he has been confined too closely to the bare necessities; but in adding the luxuries we must be careful not to eliminate the educating power of a moderate and plain life. Superfluities are dissipating of one's energies, and weakening of the moral fiber, whereas simplicity is economy, and makes for straightforwardness and therefore for power.

One's amusements have much to do with his power, for they force their own example on the mind and they either divert or conserve one's energies. And here is where the farm lad has a great advantage : he is not diverted with too many side interests by being consumed in social affairs. $\mathrm{He}$ is able to go at his work with singleness of purpose, and it is no part of his thinking that he must be forever amused and entertained.

Too much entertainment is a serious fault with our time. The things that strike me most, as a countryman, when I go to the city 
are the "attractions," - all the gewgaws and garish lights, and rackets of musical instruments, and exhibitions of freaks, and the glorious signs, and the appealing show, and the hosts of persons who make it their business to entertain those who cannot entertain themselves and to fleece those who want to be fleeced, and all the things to buy that nobody ever should want. And then I marvel at the enormous waste of human effort, and at the insincerity and indirection; and I wonder what might be the state of civilization were half of this energy and shrewd ingenuity to be applied to effort that would make for usefulness.

I am aware that all this display is but the driftwood on a sea that is calm and unruffled beneath the surface, and that a good part of its purpose is to attract the visitor; I know the sweet and strong lives that are behind the closed doors; but the cheap and insincere street life is a fact, nevertheless, and it is a natural entertainment-product of the city.

It is always a relief to get back to the unpretentious music and entertainment of the country 
folk. There is a sincerity about it that I seem to miss elsewhere, a kind of native heartiness and simplicity that satisfies the soul. I always enjoy the unlabored melody of the singing at farmers' meetings, with the absence of trills and effort; in comparison, the elaborate music of many of the city churches, with its hired singers and its instruments, seems not to be worship so much as performance.

Wiţh all this untutored experience there come a hardiness and a natural courage that are not shaken by weather or by common discouragements. As civilization provides the means of rapid locomotion, so it develops the desire to avoid the natural environment of our lives, and we fly South in winter to escape the cold, and North in summer to escape the heat. So far as this means change for health and recreation, it may be commendable; but when it is a desire merely to escape weather, it tends to breed weakness and evasion of duty.

(5) The farm effort is steady. It is characterized by perseverance. It is probably more completely divorced from the gambling 
instinct than any other occupation, - a fact well attested by the frequency with which the farmer of the past generation was " taken in" by the city sharper. This steadiness makes for continuous effort when the boy takes up some other business. The real farmer goes into farming as a lifework, not as a makeshift, nor with any idea of ever changing his occupation.

(6) The farm boy is compelled to be frugal of his money. The farm is capable of earning more money than it commonly produces, and the farmer, being a producer rather than a trader, does not receive his share of the wealth that he helps to create; but I hope the time will never come when the merit of farm life will be only its wealth.

The love of ease and of pleasure comes with much money, and it is growing, and it is also fatal to the greatest success; for necessity is the best of disciplinarians. I know it is now the fashion to underrate the importance of careful economy in money; but one cannot be spendthrift of money without being spendthrift of 
energy. In my teaching experience, I have always been conscious that the farm boy will accomplish as much with one dollar as the city boy will with two dollars, and will make as good use of himself at the same time.

(7) The farm boy develops slowly and naturally. His youth is long, in a time when our rapid civilization tends to eliminate youth. What schooling he gets has time to soak in and to become a part of him. He comes to manhood fresh and with something to learn.

$\mathrm{He}$ is in the midst of things that are not forced beyond their time, for trees and birds and the grass grow naturally and in their seasons. The constant contact with farm animals develops a kind of naturalness that can scarcely be acquired in any other way.

(8) He has an honest appetite and an intrepid digestion. The farm diet no doubt needs correcting, but in spite of its faults the average farm boy is rugged and unpampered. Later on, he may suffer from the lack of proper physical care of himself, but the surroundings themselves all make for a resistant physique. At 


\section{6 Outlook to Nature}

all events, the farm youth does not want music and pleasant-tasted trivialities to encourage the appetite. One does not need music when he eats ham-and-eggs. Eating is itself sufficient entertainment if hunger is keen and assimilation good.

(9) If the boy lives on a good farm that is paid for, he is trained in independence, for the business and the hours are managed by the family. There is no extraneous boss. In case of need, the farm can provide the necessities of the family.

Many of the strong individual peculiarities of the farmer are due directly to this independent life : he does not need to patronize. This independence, combined with isolation, often allows very undesirable traits to develop; but the general result is the producing of characteristics that we need to conserve for the good of the race.

(IO) The farm boy is a democrat. Of all our people, he is probably freest from any thought of social stratification. $\mathrm{He}$ associates with his fellows on terms of equality. The 
farmer has no servants, but " hired help," and the help eats at the table. More than this, the farm boy runs his own errands and waits on himself; and all men are equal.

(I I) The farm boy has a family life. He is essentially a home boy, not a street boy. You can fill in the picture.

\section{The New School}

A prominent school man said to me recently, "Practically no one goes from the high schools into the trades." This may be because so few of our youth go through the high school, or because high schools are not in direct vibration with the trades. My friend meant to infer the latter.

No doubt education should be supremely natural, and it can be natural only when it makes use of the forces and objects in the neighborhood. The principal of an old academy told me that he was planning to teach dairying in the school, both as a scholarship study and as a means of aiding the industry of the community. I asked him how he could 


\section{8 Outlook to Nature}

teach it without a laboratory and apparatus. "I have the ideal laboratory," he replied, " because it is an actual enterprise: it is the creamery yonder." I recognized that he was a prophet.

The new laboratories.

The science-teaching developed the laboratory. Of course it is fundamental, yet the formal laboratory is not sufficient if we are to teach also by means of affairs. It is only a collection of materials with which to work, - formerly dead things, but now live things. We cannot teach affairs in collection-laboratories: we must have actual shops, actual barns, actual enterprises, actual fields, actual gardens, - not the materials brought to the pupil, but the pupil taken to the materials. Even the farm and the shop may be made means of education.

"Object lessons" are excellent means of developing observation, but the "objects" are largely make-believe or are taken out of their natural place and thereby lose much 
of their meaning. The new "nature-study" tries to place the pupil with the objects and phenomena as they occur in nature; and so far as it does this, it is fundamental and will be abiding. The persistency with which nature-study is treated as if it were object-teaching or mere laboratory-teaching shows how difficult it is to extend the sphere of the school beyond the school-house.

\section{The material of occupations.}

The general elementary schools cannot teach trades, occupations, or professions; but they can use the materials of trades and occupations as one of the aids to scholarship, and while doing so they may give such a "set" toward the occupations as will attract all youth and will at the same time make them more efficient in their own behalf and also in behalf of civilization.

In an agricultural community, for example, all the farms of the neighborhood will afford training in the elements of failure and success. There is no reason why the 
pupils should not know why and how a man succeeds with his orchard or dairy or factory, as well as to have the cyclopedia information about the names of capes and mountains, dates, and the like; and why should not every good farmer explain his operations to the pupils?

Such work, if well done, would vitalize the school and lift it clean out of the ruts of tradition and custom. It would make a wholly new enterprise of the school, rendering it as broad and significant as the community itself, not an exotic effort for some reason dropped down in the neighborhood. When the public schools begin to touch experience and pursuits in a perfectly frank and natural way, we may hope that persons who have money to give for education will bestow some of it on elementary and country schools, where it will reach the very springs of life.

\section{Manual-training.}

It will be seen that all this is a much larger idea than customary manual-training alone. 
Good as manual-training is, it still should lead from the make-believe into something that articulates directly with the lives of the pupils and the needs of the community.

\section{The new education.}

All this constitutes the new "industrial education," - an education that uses native objects and affairs as means of training in scholarship, setting the youth right toward life, making him to feel that schooling is as natural as any other part of his life, that he cannot afford to neglect it any more than he can neglect the learning of a business or occupation, that the home and school and daily work are only different phases of his normal life, and that common duties may be made worthy of his ideals. It is the active as distinguished from the sit-still method.

Unfortunately, the term "industrial education" is ordinarily understood to mean direct training for the trades; therefore it would be a great gain to a clear understanding of the' subject if some other term could be used. The 
term nature-study will not answer the purpose, for this is commonly understood to cover what we know as " nature," not including industries and affairs. In my own mind, the term naturestudy is large enough for this, for I think of "nature," in this relation, as expressing that method of education whereby the pupil is educated at first in the terms of the world he lives in; but the term has been so long used with another signification that it cannot be pressed into service for the larger and fuller idea. I wish we might say " natural education," but this is indefinite and would always be disputed. For the time being, therefore, I see no better term than industrial education, with the reservation that it mean much more than commercial education, or than manual and technical skill for use in the arts and trades.

I have no complaint to make of the schools, but rather all praise to give. They are in the process of evolution. They have come down from the college and university, and are still essentially exotic; but a new intention will gradually redirect them. 


\section{The School of the Future}

The country school.

There certainly will come a day As men become simple and wise, When schools will put their books away Till they train the hands and the eyes; Then the school from its heart will say In love of the winds and the skies :

\section{I teach}

The earth and soil

To them that toil,

The hill and fen

To common men

That live just here;

The plants that grow, The winds that blow, The streams that run In rain and sun

Throughout the year;

The shop and mart, The craft and art, The men to-day, The part they play In humble sphere; 
And then I lead

'Thro' wood and mead

By bench and rod

Out unto God

With love and cheer.

I teach.

\section{The Ways and Means}

It may be agreed that this industrial kind of schooling is desirable, but it will be asked how it is to be brought about, - where are the schools in which it can be taught, and where are the teachers who can teach it?

These questions are asked me again and again, as if they raised difficulties that are insurmountable. But I have never felt that these difficulties are of primary importance. The essential point is to convince the public of the necessity of the new kind of education: the means will work themselves out just as they have in all other enterprises. The demand for teachers will develop slowly, and with the demand teachers will begin to prepare themselves; and as soon as the demand becomes well established, special facilities for training 
the teachers will arise. It would be reversing all laws of natural development if teachers should be trained before the need of them had become concrete; and therefore I do not wish to set up straw men or to pre-judge the obstacles.

\section{The present overcrowded program.}

I am ' constantly told, also, that the schools are already overcrowded, and that new subjects cannot be added. This shows a lack of comprehension as to what the coming education is: it is not to be merely "added to" present "courses of study," but it is in time to reorganize courses of study and even to change the point of view on education. It is to make a new kind of school, with new methods of work, new programs, and the formal book work is to be only a part of the system. The redirected school will have its own scheme and method.

The difficulty at present is that we are trying to push in additional things without giving way with any of the old; we are trying to engraft the new educational ideas on the old stock. In time the old method will go, an indigenous 
system will take its place, and the child will be allowed to develop freely and naturally, without overworking.

\section{We need equipment in land.}

If we are to evolve a mode of nature-education, we must control a good piece of land. It is pitiful to see how small and scant are the bits of earth that surround our schoolhouses.

Even in the open country there is the same stint of land, - still another illustration of the lack of any vital connection between the school and the life of the community. Often it seems as if the country schoolhouse were placed with reference to economizing the cost of land, land that, if sold, might bring as much as thirty or fifty dollars an acre!

I once taught a district school that was set on an island of hard ground in a swamp; and again one that stood on the side of a sand hill. I know of country school grounds that are scarcely larger than the building, and lying directly against the highway at that, as bare as the moon, and in a place that would not be 
given to any other important building. In many a country school the only playground is the public highway, and sometimes that is unfit for even highway uses at many times of the year.

A site that is not good enough for a country home is surely not good enough for a good country school, and the school ground should be at least as large as the home ground. I should put one acre of land as the lowest limit for a country school. This ground should be the park for the neighborhood, with an attractively planted collection of trees and shrubs, and this collection should be more useful to the school than is the mere apparatus to be used indoors. It is amazing how we have deprived our children of room, even when there is room to spare, and how completely we have committed ourselves to the idea that schooling is an affair of the inside of a building.

The school-garden.

This brings me to the school-garden, to an outdoor area where the children may work 
with actual problems. Such an area will be an essential part of school equipment. It will be an additional room or laboratory, not maintained primarily to teach the children gardening but to be utilized for educational purposes.

The school-garden will do much to place the school in proper relation to its natural problems and will be an intermediate stage between the schoolhouse and the larger environment of the neighborhood.

Various kinds of extension gardening will soon be important agencies in civic and educational work: they will furnish occupation for the unemployed; utilize waste lands; afford health-giving employment at hospitals; add interest to parks; augment the beauty of the city or town; encourage thrift and tidiness in homegrounds; increase the efficiency of schools.

The last category is the one that most interests us at this moment; therefore I will state some of the specific ways in which the schoolgarden may be expected to forward school 
work. It supplants or, at least, supplements mere book training; presents real problems, with many interacting influences, affording a base for the study of all nature, thereby developing the creative faculties and encouraging natural enthusiasm; puts the child into touch and sympathy with its own realm; develops manual dexterity; begets regard for labor; conduces to health; expands the moral instincts by making a truthful and intimate presentation of natural phenomena and affairs; trains in accuracy and directness of observation; stimulates the love of nature; appeals to the artsense; kindles interest in ownership; teaches garden-craft; evolves civic pride; sometimes affords a means of earning money; brings teacher and pupil into closer personal touch; works against vandalism; aids discipline by allowing natural exuberance to work off; arouses spontaneous interest in the school on the part of both pupils and parents; sets ideals for the home, thereby establishing one more bond of connection between the school and the community. 
The growing child.

The child is educated by the very process of living and growing up. Every object that appeals to his senses, every circumstance that arouses his emotion or stimulates his imagination, contributes to the process. The school should aid in directing all these educational forces, that they may produce the most beneficent results. The play must be organized educationally. The school has fallen short of its opportunities by confining itself too closely to a certain line of conventional effort.

In the nature rcalm, these ideas as to the influence of the environment are well expressed in Walt Whitman's poem, beginning

"There was a child went forth every day,

And the first object he look'd upon, that object he became, And that object became part of him for the day or a certain part of the day,

Or for many years or stretching cycles of years.

" The early lilacs became part of this child,

And grass and white and red morning-glories, and white and red clover, and the song of the phœbe-bird, 
And the Third-month lambs and the sow's pink-faint litter, and the mare's foal and the cow's calf,

And the noisy brood of the barnyard or by the mire of the pond-side,

And the fish suspending themselves so curiously below there, and the beautiful curious liquid,

And the water-plants with their graceful fat heads, all became part of him."

\section{The nature-attitude.}

It may be said that although I admit the educational merit of affairs and industries, I nevertheless place the main emphasis on the study of nature. This, of course, is true. How much of this attitude is the result of personal inclination, I cannot know; but I purposely put the emphasis here because nature is the necessary condition of our lives, and on the nature-basis we may build the superstructure.

\section{The content-work.}

The school effort may be roughly thrown into two categories, - the content-work and the expression-work. The content-work is the subject-matter. It is the acquisition-work, the 


\section{32 Outlook to Nature}

result of contact with objects and phases of objects. The child becomes his own investigator, unless he is asked to investigate beyond his own range, when he becomes an imitator. The content-work is the first and primary work.

Self-expression.

The expression-work is the result of the content-work; yet the old schools taught a child to express himself before he had anything to express; and herein lies the explanation of much of the educational inefficiency of the old régime, and also its failure to put the child into real touch with itself and its surroundings.

The means of expression with which we have most to do in elementary schools are speaking, reading, writing, drawing, number. These are not so much subjects to be taught, as results to be secured from the acquiring of experience with subject-matter. The industrial education will put the child into the way of acquiring original knowledge at least as early as it asks him formally to express himself. 
The result begins to be seen.

I have now tried to express my conviction that a natural and direct kind of education is slowly developing in our midst, and that the process is founded on the normal human life of the time. It is slowly shaping the common activities into educational form, and making them the means of sound mental discipline; and this is the only way whereby education can be carried to the mass of the people.

It will make the people efficient; and it will eventually obliterate pernicious distinction between the hand-worker and the remainder of mankind, and will make for both individual and corporate honesty.

The world is full of those who want to do socalled "mental work,"-clerks, bookkeepers, counter-jumpers, and office servants of all kinds, often driven to do work for the merest pittance ; and yet we have difficulty in finding skilled and independent artisans, although the work of the expert artisan is of the higher grade. The people themselves seem always to have believed in the educational value of the common activi- 


\section{34 Outlook to Nature}

ties. The difficulty has been to overcome the prejudices of the pedagogues.

The older subjects.

There is no reason why this new applicable education should in any way antagonize or even restrict the studies in language, history, literature, and philosophy, for these subjects are as important as others; in fact, they add something to the depth, fullness, and repose of life that is much needed in these intense days; and, moreover, these subjects are themselves the final expressions of the very common-day activities that we wish now to introduce, and therefore they will become a natural part of a continuous educational process. But they will not dictate the means and methods at the beginning of the educational process: they are the flower, not the seed.

\section{Old phrases.}

Nor is it to be feared that this active education will lead to "materialism." This fear is only a bogey-man. Materials are the conditions 
of existence, and are not only high in themselves but are the bases of what we call the higher aspects of our existence; and the better the knowledge of the material, the bolder and freer should be the apprehension of the immaterial.

Over against this newer humanistic education are often set such phrases as "education for manhood," "education for ideals," "education for citizenship"; but this distinction is only academic. It is no doubt true that we have made mistakes - and are still making mistakes - in beginning occupational education too early and with too complete exclusion of nontechnical subjects; but industrial education, so far as it applies to the public schools, is not professional education; and industrial and even professional education can be so managed as to train broadly for manhood and for citizenship, and the effect of all education that is worthy the name is to develop the ideals in the subjects that are touched.

It is high time that the formal and academic distinction between the old and the new education be obliterated and forgotten. 


\section{36 Outlook to Nature}

The school of the future.

There's a farm on the hillside, A mill on the river;

There's a store on the highway,

A mine on the mountain; There's a shop on the lowland, A ship on the ocean.

There's a man with his reaper, A man with his dinner; There's a man with his shovel, A man with his measure; There's a man with his tool-box, A man with his canvas.

There's a home with its comfort, A street with its goers; There's a club with its actors, A hall with its speakers; There's a church with its people, A school with its learners.

These all are God's agents.

Relentless and ceaseless

In workshop and homespun They weave the Great Fabric. They are builders of nations, They are makers of Heaven. 


\section{The School of the Future I 37}

As the race in its progress,

So the child in its nurture

And the flight of the poet

Come up out of Labor.

Constructive, creative,

Will the method of nature

Of life and its content

Make the School of the Future. 


\section{Evolution: The Quest of Truth}

$A \mathrm{~T}$ a recent Bible League Convention the A hypothesis of evolution was again refuted.

Most of us had been led to think that the old contention between the theory of evolution and theology had worn itself out, and that the theory was to be allowed to stand or to fall on its own evidence. We had supposed that the theory is accepted as a working hypothesis by all naturalists and by most publicists. We had been further of the opinion that these adherents, representing all possible points of view and being honest seekers of truth, would quickly withdraw their support in case the hypothesis were found to be untenable - in 


\section{Evolution: The Quest of Truth I 39}

short, that the burden of disproving the organic evolution hypothesis no longer rests on the theologians.

It would seem as if many people assume that there is a wicked cabal of evolutionists that hang together for the purpose of foisting their schemes on the public; but everyone ought now to know that evolutionists are themselves the most critical of every phase and item of the hypothesis, seeking always how they may prove and disprove and thereby discover the ultimate truth. Such antagonists seem to have no conception of the enormous literature of evolution, or of the multitudes of investigations by some of the most careful and conscientious workers in the world, or that our present evolution conceptions are the results of sharp conflict of opinion and long years of discussion and not of any agreement to agree. The ease with which this stupendous body of research is thrown aside by one stroke of persons whose arguments show that they are not within sight of the subject is cause only for amusement so far as the discussion touches evolution; but it may be 
worth while in any case to consider its bearing on our outlook to nature.

The evolution hypothesis.

The hypothesis of organic evolution is supposed to be an explanation or interpretation of well-observed facts and phenomena. It is well worth our while, therefore, very briefly to inquire what is the nature of the foundations on which these newest refutations rest. If the evolution theory is to collapse, or even if it is to fall into disrepute, our outlook is to undergo a radical change; and the subject becomes of far greater importance than to theology alone.

The general effect of the rise of the evolution theories is the endeavor to see things as they are, and then to interpret them without fear or bias or prejudice. Evolution stands for the quest of truth as distinguished from adherence to dogma. It affirms that the origin of the forms of life is a natural phenomenon and is governed by law. Evolution has set the face directly toward truth regardless of the 


\section{Evolution: The Quest of Truth I4 I}

consequences; and the outlook to truth in what we call the natural world is the outlook to courage, to the future, and to hope.

Point of view of the discussion.

I have no desire to put myself in the attitude of appearing to come to the rescue of evolution, nor of considering such criticisms as I have mentioned as a menace to that hypothesis. The hypothesis needs no advocates. Nor is it my purpose to make an attempt to expound the bearings of the evolution philosophy on ethics or religion, except as such discussion bears on our attitude toward the natural world in which we live.

Therefore, I use some of the criticisms and refutations merely as texts, and not that I may refute them, nor correct them, nor criticize any person. They are representative of nearly all attacks on evolution. Such general attacks are no longer frequent and they by no means represent the attitude of the clergy: in this discussion I have chiefly in mind a certain large class of the laity. Many persons accept the hy- 


\section{42 Outlook to Nature}

pothesis of evolution merely as a concession to the times.

Disproof by assumption.

Questions as to statements of fact being omitted, objections to the criticisms to which I refer are chiefly of two categories. The first and perhaps the most pertinent observation that such statements suggest is that the attacks are made by persons who are not themselves familiar either with the subject-matter of the organic evolution hypothesis or with the natural-history point of view, and that their purpose is not so much to discover facts of evolution as to bolster dogmas and traditional beliefs. Now, if the dogmas and beliefs are true and are worth the while, they will stand. They will be their own proofs. It is only falsity that needs to be bolstered.

This class of refutations is usually founded on assumption, not on reason or investigation. It is an outlook to "belief," not to nature; and yet evolution is a process of nature. Let me read: 


\section{Evolution: The Quest of Truth I 43}

"Following out an observation that in the embryonic state man passes through the different stages of worm, fish, reptile, and quadruped, the evolutionist has argued that the human race has accordingly been evolved from the worm, fish, reptile, and quadruped. This certainly is a momentous induction from limited data, indeed from almost no data at all.

"If we may speak with perfect plainness, an inexcusable blunder is committed by the evolutionists by reason of overlooking, or what is worse, by reason of a misinterpretation and false application of, the prophetic element in nature. That is, the Creator is a prophet and his method is to anticipate by type, pattern, or prophecy what may be expected in his subsequent creations. For illustration, the fins of fishes, the wings and feet of birds, and the fore and hind feet of brutes, created before man, are prophetic of the arms and feet of man. So, too, the lower forms of life, the worm, fish, and reptile, furnish hints of what the higher and later forms are to be." 


\section{I44 Outlook to Nature}

An appeal to prophecy and belief is not demonstrable, for it does not rest on evidence. Therefore it is not debatable, and is outside the realm of science, and beyond the reach of truth. Finding facts that must be accepted, it attempts to account for them by a wholly gratuitous assumption, and an assumption cannot be disproved. If a man assumes that snow is black, there is no use in trying to convince him that it is white.

\section{Disproof by misunderstanding.}

My second observation is that such refutations misunderstand and misinterpret what evolution is. For example, they confound evolution and Darwinism; but every writer now should know that Darwinism, or " natural selection," is only one of the means of explaining how evolution may have taken place. Many of our best evolutionists do not think that Darwinism is an adequate explanation. In fact, Darwin himself did not contend that it is the sole method of evolution: he stated objections to it; and this is most significant, 


\section{Evolution: The Quest of Truth 145}

because it is ideal illustration of the fact that the naturalist seeks first for truth, whatever effect the truth may have on his theories.

The hypothesis of organic evolution merely supposes that one form of life may give rise to another form, and that the animals and plants now inhabiting the earth are ascended from earlier kinds. In the main, the hypothesis explains the facts as we see them; and there is no other hypothesis, founded on observation and scientific interpretation, that does account for them. Whether the present form of the hypothesis will stand the final judgment of mankind is of little consequence: it is the most reasonable hypothesis yet propounded; and, what is more to our purpose, it opens the whole subject to investigation. Just how and why this evolution has come about are questions of dispute, but this dispute will in time bring us to a solution.

It is probable that no one agency is responsible for the entire evolution; and it is possible that all explanations, resting on scientific evidence, are responsible in some degree. Every 


\section{I46. Outlook to Nature}

working evolutionist has his own conception of the methods, which only proves that he sees with his own eyes and thinks with his own head, and that his only goal is to find a true explanation.

Our antagonist cites theories that have been abandoned or modified as proofs of decadence of belief in evolution: but in fact they are the very proofs of its vitality; they are so many stepping-stones in the search for truth. The evolutionist has no age-long dogma. Persons do not seem to realize that nowhere is there so great discussion of theories attempting to explain evolution as amongst evolutionists themselves: but there is little antagonism to the hypothesis that evolution is a method of creation.

The antagonist further evidences his lack of conception of what evolution really is by an entire misapprehension of the significance of some of the facts that he cites. I choose the following, from among other statements, merely as an illustration of a method of disproof, or evidence of "collapse": 
Evolution: The Quest of Truth 147

"And upon enlarging the field of investigation the evolutionist is confronted. with still more serious grounds for embarrassment, for there is not only no universal law of improvement, or elaboration, on which his theory largely depends, but on the other hand in scores of instances, there is among things having life a pronounced deterioration of parts and functions.

"When, therefore, the evolutionist in support of his theory says there is in the kingdom of living things a universal law of constant development and improvement, he most certainly is not telling the truth; and for one to build theories upon such false assumptions is clearly a gross violation of the scientific spirit and method."

What the evolutionist means by progress is not necessarily an increasing complexity and an addition of new parts or attributes in every organism, but rather a progressing or continuing modification. The loss of characters is just as much a process of evolution as the acquiring of characters, for it may just as 


\section{I48 Outlook to Nature}

effectively adapt the organism to its conditions. The loss of legs in the serpents, for example, is one of the clearest proofs of evolution or modification, even though we may think of it as retrogressive; for the rudiments of legs may be found in some cases, and the limb-bearing genealogy is traceable. The general movement of evolution has been toward greater differentiation and complexity, and, in our human phrase, we sometimes speak of this as "improvement"; but any modification that better relates an organism to its environment is improvement for that organism, whether the modification is the winning of new characters or the loss of characters once gained.

\section{Evolution vs. transmutation.}

A great hindrance to a belief in organic evolution is the careless use of the word " transmutation," which connotes that one species "turns into another species." The transmutation theory is really opposed to the evolution theory, for the latter theory supposes that one 
Evolution: The Quest of Truth I 49

species may spring off from another species or rise out of variations from it, the parent species usually retaining its identity.

Most of the groups of animals and plants that are definite enough to be readily described as species have probably practically completed their general evolution; they may not be able, even, to give rise to other marked forms. The world now contains species representing various grades in the process of evolution; but it is to be supposed, since the earth is now relatively stable and densely inhabited, that the progress of the creation is at present comparatively small.

\section{Evolution in operation.}

The opponents of the evolution philosophy are always asking that the evolutionist show them the process in operation; and at the same time they are very likely to beg the question by affirming that animals and plants are not now changing. This latter position is strongly maintained by the antagonist whom I have been quoting: 
"Beginning with what is called 'the primordial zone' which covers the earliest stage of biological history and coming down to more recent times there will be found, as a matter of fact, multitudes of species that have shown no improvement since their creation. The algæ or seaweeds, that appeared in the distant Silurian deposit, millions of years ago, were no less perfect than those of the same class found in our modern seas. The oak, birch, hazel, and Scotch fir, easily traced back at least to the ice age, have remained in all these thousands of years without the slightest improvement.

"And, too, in the animal kingdom the same discoveries are made; the insects that built the first coral reefs of Florida, in the three hundred centuries of their existence show no improvement."

It is not true that evolutionists hold that all animals and plants are now in process of active evolution. Some forms are essentially matured, some have passed their zenith and are in process of extinction, some are long since lost, others are just now in the stage of marked de- 


\section{Evolution: The Quest of Truth I 5 I}

parture. Some of them may remain for centuries without important change.

But I object to the above quotation because of its method or outlook - it is again the method of dogma and not of search for scientific truth. Every instance must be explained on its own evidence, if it is to come within the realm of genuine quest. No one knows whether " the oak, birch, hazel and Scotch fir have remained in all these thousands of years without the slightest improvement," or whether the coral polyp has remained the same during tiree hundred centuries. Because we can match individual fossils with organisms existing to-day, it does not follow that the two are identical in structure, function, or longevity; and even if it did, this fact would constitute no disproof of evolution. There are positive instances enough to make us believe that evolution takes place.

\section{Evidences of Evolution}

We can see abundant evidences of the continuing process of evolution if we know what 


\section{52 Outlook to Nature}

to look for and are willing to believe what we see.

At one time I planted roots of wild strawberries that were received from Oregon. I gave them a warm and pleasant knoll in the back yard and they grew and thrived. I had photographed the plants before they were set, and had taken botanical specimens from them. I made similar records of the plants after they became established in their new quarters, and at the end of two years I found that the distinguishing ancestral marks had disappeared, and I had a new type of plant. This discovery so delighted me that I told my friend of it, and said I believed that I had really produced a new species. The friend, however, at once became serious and said that such a remark is heresy and that I should straightway look to my conscience. This staggered me, for I had not thought of it before as a question of ethics or even of philosophy, but only as a question of fact; and I was astonished, as I now thought of it, to find how sinful a simple fact may be. 


\section{Evolution: The Quest of Truth I 53}

I returned to the strawberries on the knoll, where they lay so innocently in the sun; and were it not for my friend's suggestion and for the bees fighting in the blossoms, I should have seen no morals in them. It became evident, however, upon reflection, that I had made a grievous fault in my terminology : I had used the word "species"; if I had said "kind," there had been no offense.

\section{The species bogey.}

It is about this technical word "species" that the battles of evolutionists and theologians have raged for the last quarter-century and more.

The ancients did not know this species-conception, because they knew and cared so little for the external creation that they gave small thought to the kinds of animals and plants. But with the restoration of knowledge, nature came to be more and more intrinsic to man, and persons began to wonder whence and why organisms came. With the attempt to describe or to inventory natural objects, there arose the 
conception of the "species" as something fundamental, a real entity or originally created thing. There was little attempt or desire to look at the external world broadly and to discover its method and meaning. The mind rested on the objects, and naturally exalted them and their direct progeny into units in the creation. As there was no knowledge of whence and how these units came, they were conceived to be the direct and immediate handiwork of the Creator; and there was therefore no occasion for speculation or inquiry.

This human formula of species-units was projected into the Scripture record, as if that record read, "Let the earth bring forth species of grass," and "species of winged fowl." The idea of the finished and completed speciesproduct became indelibly associated with theological teaching, and was - and, in fact, is a genuine dogma. If this species-dogma had not become so intimately associated with theological and biological beliefs, the hypothesis of evolution, when it finally came into the world, would have had few combatants. 


\section{Evolution: The Quest of Truth I55}

But are there not species, after all? Surely there are the red maple and the sugar maple, the rose and the cabbage, the horse and the dog. True enough; but we now conceive these to be the products of evolution, the result of the creation, not the beginning of it. The great Linnæus's definition is typical of the older mind: "We reckon as many species as there were forms created in the beginning." That is, there are as many trees in a garden as had been placed there. When, however, we are no longer justified in assuming origins, we must base our conclusions on evidence. We shall then count how many trees there are in the garden, and we may find more or fewer than were placed there in the beginning.

\section{The return to evidence.}

But I must not forget my strawberry. A hundred and fifty years ago a strange strawberry made its appearance in the gardens of Europe. Some persons said that it came from South America, and others that it came from North America: but nobody knew its history. 


\section{56 Outlook to Nature}

Botanists considered it to be a good species, and it was named Fragaria grandiflora. This Fragaria grandiflora is known to have been the parent of our common garden strawberries; yet the botanies have been discreetly silent as to the nativity of the plant. Now, the evidence shows, so far as I could interpret it, that my little strawberry, taken from the woods of Oregon, varied into Fragaria grandiflora in two years. In Oregon it is known to botanists as Fragaria Chiloensis (for it grows in South America as well, and was named from Chilean specimens). If Fragaria grandiflora was a "good species" before my experiment, it was equally good afterward, and, as measured by the actual practice of botanists, a new species had arisen from an old one.

When I showed a botanist my results, he said that the very fact that I had been a witness of this transformation is proof that the two plants are not true species. I replied that I was sorry that I had not closed my eyes when passing the patch, and I also suggested that his species were founded upon ignorance of their 


\section{Evolution: The Quest of Truth I 57}

origins; but he insisted, although himself an evolutionist, that my having caught the plant in the act was enough to outcast the form which had had the presumption to appear. My ethical friend had shown me the sinfulness of my little fact, and now the scientist had told me that observation is heresy; but the strawberry thrived.

It does not matter to the strawberry or to me whether it gave rise to a new "species" or not. It was a new form or a new kind; and this simple experiment enabled me, as I verily believed, to reconstruct the genealogy of the garden strawberry. It is apparently a modification of the Chilean strawberry, introduced into Europe by Captain Frezier about 1712. The unnoticed modification of this strawberry, under cultivation, had added one more species to the infinitude of species; but my accidental discovery that the species was apparently the result of modification has stricken that species from the lists; and thenceforth the backslider, if mentioned at all in reputable systematic botanies, must be only a variety or form of Fragaria Chiloensis. And what has occurred 


\section{58 Outlook to Nature}

in the strawberry has occurred with many other plants under cultivation.

Species-making in practice.

All this means that species may not, in practice, be foun' $d$ on essential or intrinsic characters, but that the word is applied to any group of animals or plants which is so distinct from other groups that a name may be given it for convenience' sake. The name makes it possible for us to write and talk about the objects, but the name, as used at present, has no other value.

And it indicates how personal a thing a species is, how much it is a matter of judgment of the man who makes it. Regel thinks that there are but two species of grapes in the northern hemisphere, whereas Munson contends that there are twenty-five species in the United States alone. Now, the grapes are the same whether seen by Regel or Munson; but Regel is not Munson. In other words, species may be matters of opinion, rather than matters of fact. 


\section{Evolution: The Quest of Truth I59}

Many garden plants and most domestic animals are further removed from their parental stems than the strawberry is, but history often supplies the connecting evidence and enables us to identify the offspring with the ancestry. But when history is silent, we may be able only to guess what the original form may have been, or we may say that the parental species is extinct. It is probable that very few of the original forms of our domestic plants are actually extinct, but the evolution has been so great that we can no longer trace it.

It is most significant that of very many of the common and long domesticated plants we do not positively know the wild originals. Of such plants are apple, peach, apricot, almond, orange, lemon, wheat, rye, barley, bean, winegrape, Indian corn, cotton, flax, sugar-cane, tobacco, sweet potato, banana, pumpkin and squash, and many more. And who knows what was the ancestral form of the ox, sheep, cat, and dog?

I must not be understood as saying that there are no distinct types in nature, or that it 


\section{I60 Outlook to Nature}

is an error to talk about species, or that there are always intermediate forms. My argument is that species are not original entities or startingpoints but that the groups which, for convenience, we name as species, are the present-time results of a long process of modification. Eventually, we may limit and refine our definition of species and we may find a real physiological basis; but of course I now have in mind the practice of the present day.

The missing links.

Those types which are most pronounced and distinct are usually those in which evolution or change is most nearly completed; and those old types that are unique are the ones in which has probably begun the slow decline that ends in extinction. The mastodon has perished, and his tribe is disappearing; the giant conifers of other ages are represented in the isolated groves of sequoias (there were giants in those days !); the tulip tree or whitewood, the sassafras, the ginkgo, the scouring-rushes are now a broken and ragged army slowly but surely 
Evolution: The Quest of Truth I6 I marching to their doom. As the numbers become less and less, as the changing environments and the inexorable grasp of time lop off the aberrant and sportive forms, these patriarchs become reduced to a single racial stem and, like the one remnant of a decaying family, perish at last into oblivion. What was once a chain becomes a series of detached and broken links; and the lost and missing links comprise the proof that there was a chain.

The tree of life.

Evolution is not a line: it is a genealogy. It is a tree of numberless branches, each branch forking again and again. The tip of one branch grows faster than its twin and thereby. leaves the other behind; so that we now have the examples of many of the succeeding stages of development. It is not unlikely that something very like the first forms of life still exists on the earth. The present groups of animals and plants are the tips of the branches in the multifid tree of creation.

It is evident, then, that the missing links 


\section{I62 Outlook to Nature}

lie behind, not between. The genealogy is the missing link; and in many cases it is traceable. There are still many unfortunate persons who think that evolutionists teach that man came directly from the monkey. It is not strange that we sometimes think so. The truth is, no doubt, that the two came off a common stem in ages past, and that they now represent the tips of the branches of a letter Y; but I like to think that the human branch is a little longer than the monkey branch.

Two underlying considerations.

There are two general reasons for believing that there must be evolution: The fact that there must be struggle for existence because the earth is not big enough to contain all the possible offspring of the plants and animals living upon it at any given time; and the fact that there have been mighty physical changes in the earth, changes which, in many cases, are not yet completed. Consequently, organisms must either have changed to meet the new conditions, or have perished. It is impossible 
Evolution: The Quest of Truth ${ }_{1} 6_{3}$

to conceive of a perfectly stable and stationary creation. If all offspring were to be precisely like their parents, competition would soon become inconceivably more intense.

\section{Direct considerations.}

Objective evidences of organic evolution may be ranged as following:

The testimony of paleontology, or the torn and broken pages of the book of life preserved to us in the rocks.

The evidence of embryology.

The evidence of comparative anatomy and physiology.

Resemblances of types - or genealogies which allow objects to be classified.

The evidence of successive increase in complexity and differentiation, or the growth of "the tree of life."

The great fact of adaptation to environment.

The vagaries of distribution, which are best explained by the evolution hypothesis.

The fact of variation, and the frequency of intergradient forms. 
The observed behavior of plants and animals under domestication.

The processes.

While these various categories of facts and evidence force the conclusion that there has been and is evolution, they are not explanations of its process. The philosophy of the mechanism of evolution has been the subject of the past-century inquiries, headed by Lamarck and Darwin; and in following the details of this speculative natural history one obtains the clearest and most personal conception of the continuing creation.

Evolution in operation.

But there is really little dispute among biologists as to the fact of evolution The controversy turns on the means of evolution - the processes by which it has come about. Yet the reader asks to see the process actually going on. I wish he could have seen my strawberries; but, then, he would not have believed his eyes if he had scen. 
Evolution: The Quest of Truth I 65

Of course, the lifetime of a man is a short span in which to catch and to observe the movement of creation; but if my doubting reader will come with me into the fields, I will show him the process going forward. $\mathrm{He}$ will see it in the many intermediate and local differences in animals and plants. Here a plant grows stronger and there weaker, here erect and there decumbent, here it is small-leaved and there largeleaved, and so on through all grades of unlikenesses and combinations of unlikenesses.

Naturalists are now divided as to whether common differences grow into relatively permanent or specific differences, but there is no doubting the fact of variation or fluctuating changes; and if species are the results of "mutations" or jumps, these mutations are only one kind of variation or difference.

There are numerous groups in which evolution is evident to the close observer. These are the groups that are perplexing to the systematist. They refuse to fall into 
I66 Outlook to Nature

any scheme of classification, and rebel at the paragraphing into distinct categories (or species) to which, in an age of formalism, the organic creation, like the Scriptures, was subjected. Among common plants, some of these groups are the asters, brambles, golden-rods, cucurbitaceous plants, strawberries, grapes, plums and their kin, and many of the sunflower-like groups.

\section{Geographical differences.}

Some of the best illustrations of the separating of two or more species from a parent stock are afforded by so-called geographical species. A certain species of wild grape extends from the humid climate of the Atlantic seaboard to the arid country of Texas. It was first made known from eastern specimens and was named Vitis æstivalis. Later on, Texan specimens were described as Vitis Linsecomii. In these extremes the two grapes are perfectly well distinguished and have every merit to be ranked as distinct species. In the intermediate country, however, they merge and are indistinguishable. 
Evolution: The Quest of Truth 167

Therefore, for purposes of description and classification, one must be regarded as a variety of the other. If, however, a mountain chain or an ocean separated the two geographical regions, and thereby blotted out the intermediates, there could be no hesitation in awarding specific rank to each.

This case is typical of the progress of creation: each geographical area has plants and animals peculiar to it, and in proportion as an area is disjoined and unlike others are its living forms peculiar and distinct. Many American plants are very like those of Europe, but the Atlantic Ocean so completely eliminates the possibility of intermediates that botanists regard the plants as geographical species. Thus we have another illustration of the fact that species may be defined not alone by intrinsic characters, but by personalities, and often in terms of mountains, plains, and oceans.

Darwin's conception.

It may interest you to have Darwin's view, as expressed in the concluding paragraph of his 
"Origin of Species": "It is interesting to contemplate a tangled bank, clothed with many plants of many kinds, with birds singing on the bushes, with various insects flitting about, and with worms crawling through the damp earth, and to reflect that these elaborately constructed forms, so different from each other, and dependent upon each other in so complex a manner, have all been produced by laws acting around us. These laws, taken in the largest sense, being Growth and Reproduction; Inheritance, which is almost implied by reproduction; Variability from the indirect and direct action of the conditions of life, and from use and disuse: a Ratio of Increase so high as to lead to a Struggle for Life, and as a consequence to Natural Selection, entailing Divergence of Character and the Extinction of less-improved forms. Thus, from the war of nature, from famine and death, the most exalted object which we are capable of conceiving, namely, the production of the higher animals, directly follows. There is grandeur in this view of life, with its several powers, having been originally breathed 
Evolution: The Quest of Truth 169

by the Creator into a few forms or into one; and that, whilst this planet has gone cycling on according to the fixed law of gravity, from so simple a beginning, endless forms most beautiful and most wonderful have been, and are being, evolved."

\section{Some Consequences of the Evolution Teaching}

I have now indicated, in a most sketchy way, a few of the evidences of evolution. I have chosen to speak of only the most familiar cases, because they are seldom mentioned in contemporary writings, and because they seem to me to be among the best proofs of evolution. We have been looking so far into the past, have searched so diligently for great facts, have so urgently desired to see the missing links, and have so confounded ourselves with philosophy, that we have forgotten to go out and see the creation going on about us.

Having taken this brief survey, we may now consider some of the consequences of the 


\section{I70 Outlook to Nature}

evolution teaching on the common outlook to life.

The new attitude of mind.

Nothing is more apparent than that the evolution type of mind is itself an evolution. It has evolved slowly. The evolution conception was certainly present with the Greeks. In an indefinite way, it began to modify men's opinions long before it finally expressed itself concretely in the works of the great modern naturalists. Its great teachers have been in advance of their time.

The opinions held by men are so many epochs in the enlarging capacities of the mind. These opinions show as clear a progress of evolution as do the changing structures of bones or the modifications of functions. The opposition to evolution is itself a stage in the process of evolution.

The new natural history.

In the natural history domain we are rapidly emancipating ourselves from the book dogma 
Evolution: The Quest of Truth I7I of "species." This is well attested by the recent theories of De Vries; for the very essence of his contention is that differences between organisms must be measured by their qualities, not by their names.

In the popular realm it is attested by the great attention that we are giving to individual animals as personalities rather than to species and groups. We are asked to consider the habits and history of one individual crow, for example, and we may name him Silver Spot rather than Corvus Americanus. The Burroughs-Long controversy, aside from its incidents and its disputes as to matters of fact, raises the deeper question as to how far particular animals have strong individual traits that are not common to the species as a whole.

In fiction and narrative, this question expresses itself in the making of an animal the "hero" of the story, as in "Black Beauty" and "The Call of the Wild."

These latter modes represent the natural way of knowing the out-of-doors. This is the way that the boy and the hunter know it. The 
boy knows what the squirrel does day by day, - where it lives, when it goes and comes, what it eats, what it says. He knows the fields and the woods and the fishing-hole, without knowing that he knows them. If we could have the intimate unconscious boy kind of knowledge put into books, it would almost make a new natural history. It would give us the life-story of the animal or the plant the whole year round. Such an author would give us the animal squirrel, not the species squirrel. This kind of knowledge is not yet in books to any great extent. Consult your authorities, and see how little explicit knowledge you find in them.

One reason why the nature-studies are so difficult to establish is because there are almost no books to serve as guides to the intimate and particular life histories. We need a new type of monographs, written directly from the field, without reference to the museums or to the kind of information that we have read about. These will contain the least possible contamination of the author and the greatest possible content of crow or frog. 


\section{Evolution: The Quest of Truth I73}

The nere application of natural history.

The study of evolution gives us comparable knowledge. We learn the route by which we have come, and we secure new light on hygiene and disease as well as on structure, new meanings on sex and on breeding; and all these must mark departures in the discussion of social and moral questions. As man is part of the evolution, so do we begin to see his problems in a biological aspect and to study them in the light of their origin and tendencies.

New attitude toward institutions and affairs.

The evolution point of view has modified teaching and the school. It has enforced the importance of the natural order, and of original and personal experience. With the great multiplication of human interests, the school has become overburdened and complex. We shall return to simplicity; and the child will begin with his environment and himself, rather than with the universe and some one else. This point of view is working itself into the 


\section{$174 \quad$ Outlook to Nature}

methods of our schools; but we have not yet learned what may be omitted from courses of study.

Evolution has modified or even reversed our attitude toward history, philosophy, and institutionalism. We now consider all questions from the point of view of their origin, development, and destiny. All activities are becoming scientific.

The inroads of evolution are most marked in those fields that are most dominated by dogma and tradition; and this is why its conflict with theology has been so long-continued and so intense. But it is emancipating religion, as it has emancipated all else. Even theology must be scientific: it is the theory of religion, and religion, if it is vital, must grow and change in its expression as new conditions arise. Least of all, can religion afford to seem to be afraid of the truth, whether in the natural science sphere or any other sphere. Dogmas, beliefs, and theories are only temporary and partial means of expressing our conceptions; as our conceptions enlarge, the dogmas expand or 
Evolution: The Quest of Truth I75

break. Truth only is divine: dogmas and beliefs are human.

New attitude toward others.

Evolution is the point of view of otherism and altruism.

It was the old idea that the earth is the center of the universe: this geocentric doctrine Copernicus disproved. It was the old idea that all things exist merely to please man: this hominocentric doctrine Darwin disproved.

Every animal and plant lives for itself and apparently as completely as if man had never existed. The recognition of this fact is one of the first steps toward a real regard for the rights of others, and consequently toward elimination. of selfishness. Yet we still seem to think that every animal and plant was created for some purpose other than for itself, and we are always asking what every organism is "for."

New attitude toward the quest of knowledge.

There is no longer any necessity to fear to accept what we see, and what we have good 


\section{I76 Outlook to Nature}

rational reason to believe does exist or has existed. We have set out with the determination to discover the origin and meaning of the world in which we live; and evidence is rapidly accumulating.

As yet, we have only a few fragments here and there upon which to construct any general theory of cosmogony, and, therefore, of life and destiny. Yet there is every reason to believe in the consecutive uniformity of action of great primal, underlying agencies. The fragmentary phenomena which we are able to observe are parts in some great system. The philosopher should therefore be able, from a study of even fragmentary knowledge, to construct a retrospect and to make a prophecy. Science gives us prevision.

If we conclude that the sun will rise tomorrow because it rose to-day and yesterday, we may then fairly assume that the evolution plan of creation will be as true to-morrow as it is to-day; and if it is the plan of creation today and yesterday, we assume that it was the plan in the beginning. We are willing to be- 


\section{Evolution: The Quest of Truth 177}

lieve that all the organic world has come from one starting point, and that every living thing is the result of the ever-continuous modification of the life-stem.

We are willing to believe more than this, so far as the evidence may take us; to believe, in short, that the visible universe has taken its present form as the result of physical forces of which, in their lesser expressions, we may have common knowledge. Worlds, like men, grow old and die. The marks of senility may even now be apparent in this earth of ours, which seems to us so young. With the receding and absorption of the waters, great areas have become deserts - perhaps the beginning of that great decline which must end in death. The moon seems to have run its span of life, and there is evidence that Mars is now far advanced upon that arid course which leads its inhabitants onward to extinction. It is conceivable that the planets will fall again into a central mass and thence again shoot forth to begin a new creation. We do not know whether this cosmos that we see is the first or the millionth! 
Oh Mars! Sister in the stellar void -

Thy course far run upon the great abyss -

Send us thy message !

What hast thou learned in thy great life,

What hopes are thine, what doubts removed,

What dost thou see beyond the veil,

What meaneth life and death?

\section{An Evolutionist's Outlook}

If one holds such views as these, you want to know his attitude toward God and religion. I do not assume to contradict any man's theory of life, and do not desire to impress my own opinions on any mind. Neither have I any suggestions to make as to conduct or to what is conventionally known as "character"; every man must work out his own life: and as he thinketh, so is he.

\section{It is not a verbal revelation.}

Now, as I think of it, there are two considerations that lie at the bottom of this whole matter. In the first place, even if my strawberry did originate another species, truth and love and mercy have not changed. In the 


\section{Evolution: The Quest of Truth I79}

second place, I have no reason to deny God to-day because I misunderstood him yesterday.

The means and methods of creation are not a part of revelation. The Scriptures have quite another theme. Only the general course and sequence of the creation are outlined; and it is marvelous that the most advanced teaching of evolution should so fully confirm the sequence of Genesis. I find nothing in Scripture to make me disbelieve evolution. Man has interjected his own conceptions of the means of creation into the Mosaic symbolism, and has thrown them into his creed; and if that creed must now be overthrown, the fault is man's, not God's.

The search for God.

But where is God, in all this great and evolving scheme of creation? I answer that he is where he always was. Nothing that man can do can make the creation any the less true or untrue; and what a man thinks he saw in a strawberry plant need not lessen his faith in a creator any more than it shakes his faith in a 
creation. Strictly speaking, evolution does not attempt to explain creation, but only the progress of the creation. Whatever its form, it begins where Genesis begins - "In the beginning, God."

It will afford me much satisfaction to say that some of the attempts of the theological apologist to find a place for God in the evolution scheme are the merest quibbles, - I have in mind a debate in which I once engaged. He turns the leaves of Darwin or Huxley and as often as he finds the word "plan" postulates a planner, and if he finds "design" affirms a designer. Now the fact is that these words are borrowed from common language to express ideas for which no plain technical words exist. The naturalist uses the word "plan" to designate a type of structure, or a marked tendency in any group, and "design" to indicate the idea of a proximate or immediate interference of the creator. Neither word has reference to purposiveness. It would be as true to say that when a naturalist uses the word "type," he thereby postulates a type-setter. 
Evolution: The Quest of Truth I 8 I

There is another method of search for God in the creation, which we should consider in passing. Being no longer able to see the special interjection of a divine hand in the making of species, the seeker desires to find him in the variations or mutations from which species arise. This supposes that variation is definite and designed, and that it is the special work of the hand of the Creator. Of course there is no satisfaction in any such makeshift as this, for, as there is no necessary difference between what men call species and what men call varieties, we may as well assume or deny special creation in one as in the other.

Driven from this position, these persons next fall back upon the origin of life - for life certainly must have been specially created. It is true that we do not know whence and how it came. Now, to me, it does not matter whether life was specially created or whether it was first the result of chemical recompounding, or of other so-called " natural" forces. If it is the result of natural forces, then I want to know it, and I should dearly like to see it 
making; and I should thank God if he allowed me so close a view of his methods.

We are not to search for God here and there, as if we were afraid he would elude us, but we are to see him everywhere; and we must be willing and ready to see nature as it is. Truth is the standard, and no creed or dogma should close our eyes to the facts and the beauty of the external world.

It is to be expected that our conception of God will enlarge as our horizon enlarges. This conception is of course anthropomorphic, founded on human attributes. Evolution implies that God is not outside nature, but in nature. He is immanent, not absent.

Nature must ever be our recourse; its facts and its voices must be heeded; one may well exclaim with Wordsworth :

“ Great God ! I'd rather be A pagan suckled in a creed outworn; So might I, standing on this pleasant lea, Have glimpses that would make me less forlorn;

Have sight of Proteus coming from the sea, Or hear old Triton blow his wreathèd horn." 


\section{Evolution: The Quest of Truth I 83}

\section{Heaven.}

A woman who knew my evolution beliefs once asked me where heaven is. There seemed to her to be no place left for it in the cosmos of the evolutionist.

I could only answer that I never expect to be able to discover heaven with a telescope. Perhaps heaven is much nearer than we think. Do we expect to locate a scene of which the very plan and elements are so far beyond human cognizance that they cannot be revealed to us?

This is a type of difficulty that perplexes many persons. They dwell upon the physical symbolisms of faith and creed, as if the things of the spirit must be measured by time and space and materials.

One has but to reflect upon the varied pictures that we have of heaven to discern that Scripture and experience reveal only the fact of heaven, not the vision of it. To the Indian, it is the happy hunting ground; to the weary, a home of rest ; for the wandering disciples, a house of many mansions; to those liv- 


\section{Outlook to Nature}

ing under the Roman influence, an eternal city ; to the inhabitants of desert-bordered Palestine, a scene where waters fail not; to John, banished on Patmos, a place where there is no more sea. If we have only symbols of the other world, how futile to ask where Elysium is !

\section{The vast program.}

To me, the entire evolution scheme is a program or design; and the fact that we have only now been able to apprehend this scheme is all the more proof that it is divine.

But creation cannot be a true design or scheme if special interference in particulars is necessary to carry it forward. Likewise, a scheme that applies to some groups and not to all, or in which special creations are now and then invoked, is disjunctive and discursive, unable to support itself, and therefore unworthy a divine hand. A powerful reason for ascribing the entire creation to an almighty hand is the very fact that it has within itself the power of unfolding and developing throughout space and time - the fact, indeed, that it is an evolution. 


\section{Evolution: The Quest of Truth 185}

Considered as a methodological question, the hypothesis of evolution is either true or not true. It cannot be half true and be evolution. I see design in it because it postulates uniformity of force and action. The idea of special creation postulates change of purpose or at least incompleteness of design. It infers capriciousness. Much of the creation is meaningless unless we conceive all its parts to have organic connection. The idea of a creator interfering in his creation, and constantly reinforcing and mending it, is typically human, suggested by the workshop, and is unworthy of a creator. The creator is not a mechanic.

If the cosmos is a design, it must follow, of course, that there is design in its parts; but the design in the parts is the unfolding of the law of design, not special interference in particulars.

The place of the individual.

To the individual, the evolution conception enforces the importance of the person as dis- 
tinguished from the mass. It stands for the voluntary life. Each organism has its own work to do, its own struggles to overcome, its own perplexities to solve; and it can be itself only when it is master for itself. Each organism is a part in a fabric, but each helps in its own way in the general movement toward destiny; and it cannot escape the burden of its own part unless it die.

When intelligence has appeared, the organism rises above its circumstances in a measure, and it may have a choice of alternatives; but it cannot choose to cease to play its part in the progress of life.

Man is a part of the evolution record; he is partaker in the process, not a passive lookeron. He is democrat amongst democrats, not autocrat created of some different and cleaner stuff. What supremacy he has is what he wins. The pride of effort and accomplishment is better than the pride of origin. Effort works out of us the selfishness and arrogance. There was need of the rise of some hypothesis of altruism and tolerance, for nothing could have 


\section{Evolution: The Quest of Truth I 87}

been more self-centered than the old creeds that elected ourselves to be saved and others to be doomed. Salvation is not the highest goal of religion: gradually the emphasis is being transferred from salvation to service.

The truth shall make us free.

The evolution philosophies have changed our point of view not only toward what we call nature, but toward all problems of life and destiny. They demand that we be willing to free ourselves from every bondage of doctrine and dogma, from traditions and superstitions, from "authority" and prejudgments, and that we regard every subject the human mind can grasp as proper for unhindered inquiry.

The biological speculations are emancipating us. This emancipation is not yet complete; for few of us are yet willing to believe whatever may be true, or to commit ourselves unreservedly to a quest of the truth as evidence and reason may direct us. This new outlook opens the cosmos for observation and for study.

These vast studies are taking us back to the 
facts. They teach us to accept the evidence of experience and the objective demonstrations of natural science, and to build on them our philosophy of life, rather than to try to make experience and evidence match a system of metaphysics.

\section{Evolution and religion.}

It is said that evolution gives us no new faith for that which it destroys. Evolution is not a faith; it only releases us. It destroys no faith, except as doctrines are shattered if they do not match with experience or seem reasonable in the light of our expanding knowledge. It tends to strip the practice of religion of its non-essentials.

The organic evolution hypothesis is but one of the results or expressions of the study of science, and probably it is not the boldest expression that the world will see. Natural science stands indisputably for truth in its own realm, and, therefore, makes for truth in all realms. It stands for absolute honesty and frankness, and for the accumulating of evidence. It stands for the fair, open, and 


\section{Evolution: The Quest of Truth I 89}

convincible mind. Its whole tendency is toward higher ideals, and it is this idealism that is thrusting old forms aside in order that it may find the precious crystal of Truth.

Just now it seems as if we were left somewhat adrift in our faiths; but this is because we have not yet been able to readjust and restate our religious outlook. Religious experience is undergoing a new birth, but we shall not cut loose from the past. We shall keep all that is divine. We shall formulate a new theology that will be more helpful than the old.

It is asserted that the modern evolution studies tend to decrease church-going. I do not think this is because these studies antagonize religion; but the man who comes fresh from a study of objects and phenomena often finds the service and the sermon so contrary to what he observes is the course of nature that they fail to hold his interest. They may seem to him narrow and inadequate and verbal, and therefore the church may depress rather than stimulate him.

On the other hand the layman, immersed in 
his investigations or affairs and expending his energies in them, may be little aware of the progressive attitude of the church as a whole, of its full acceptance of the results of scientific research, its growing spirit of freedom from the non-essentials on which men differ, the new leadership that it has acquired, and the great share that it is contributing to the constructive movements of the time. The tendency is for men to determine where they agree rather than where they differ, and to coöperate in a large way for the public good.

We are less and less interested in theories of religion as guides to action. Every heresy trial seems to emphasize the importance that is attached to "beliefs" rather than to essentials. The world cares less for what a man passively "believes" than for what he is and what he accomplishes.

The world needs fine, bold, constructive, spiritual work, something that appeals to the forceful, creative energies of able, active men. This, in fact, is the very tendency in spiritual work to-day; and it is for this 


\section{Evolution: The Quest of Truth I9I}

reason that we are to expect a strong revival of religious feeling. The world never needed great spiritual leaders more than now, perhaps never so much as now, when old formulas are falling apart, when industrialism is rising with enormous rapidity, when wealth is increasing and is placed at the disposal of altruistic enterprises, and when we begin to realize the brotherhood of man. Perhaps the day of much preaching is passing; but the day of the pastor and the minister is coming.

If we are to have naturalness in teaching and literature and science, surely we should have it in religion. I think that we have overemphasized the supernatural element. Religion is as natural and as normal as other human activities and aspirations. It is itself an evolution.

Just how we shall formulate the evolutionidea into religion, only the future can tell; but I see no reason for apprehension or doubt. It is evident that the evolution teaching is helping to place religion on a rational and scientific basis. I think that every minister 
should be a naturalist, - using the word in its large and etymological sense.

\section{The passing of fear and doubt.}

Religions are founded more or less on the philosophy of fear, or have been much dominated by it. The forces of nature are beyond us and about us, - the flood, the fire, the rain, the lightning, the earthquake, the pestilence. We appeal to supreme beings to protect us and to provide a way of escape, and we make sacrifices, ask for propitiation, and beg for mercy. We are set over against the great awful universe in which we live.

But if man is in very truth a real part of nature and has come up through what we call the natural processes (but they are divine processes, nevertheless), then he feels and respects his brotherhood with nature, adapts himself hopefully to his conditions (since it is useless to adapt himself unhopefully), and he fears not. We are learning how to control the forces of nature, and we are beginning to feel the courage that comes from mastery. We shall then look 


\section{Evolution: The Quest of Truth 193}

for the end of fatalism and of mere hopeless resignation. The devils are vanishing.

Our nature poetry is tinctured with the philosophy of fear and of dread. Or much of it is mere praise and exaltation of nature. Very little of it catches the spirit of the real fellowship of man and nature, - that creation-spirit which will come from the full understanding of our origin and our relative place in the cosmos. We have much that we call nature poetry, but most of it will not be nature poetry in the time to come.

We are to pass the Age of Doubt. We are caring less for "belief" and therefore there is less reason for "doubt," - for "doubt" is the complement of "belief" and originates because we cannot believe the belief. The verities of religion lie deeper than beliefs or dogmas or formulas. We shall cease to bolster and reinforce faith by artificial and arbitrary means. Freedom and simplicity are requisite to great religious growth.

Faith will be direct and free, as natural as the trust of the child, as native to us as the 


\section{94 Outlook to Nature}

sunshine and the air. We are coming to a religion of joy and activity, full of high spirituality, of great trust in nature, of hope in man, and of direct dependence on the Almighty.

\section{The outposts.}

The evolution-conception of the universe, therefore, bids us come and stand on a high place. It magnifies individual effort, kindles the inner light of conscience in distinction from authority, lessens belief in mere wonders, stimulates the reason, and emancipates the man. It asks us to lay aside prejudice and small dogmatisms. It impels us to a new and great reverence for the Power which has set in motion that stupendous enterprise which unfolds itself without a break or change of purpose, setting the stars in their courses and molding the strawberry into its new environments, losing no detail in its mighty swing and running on to destiny in ages hence of which we cannot yet perceive the meaning. It bids us put ourselves in line with the movement of the ages, to throw 


\section{Evolution: The Quest of Truth 195}

aside all mental reservations and oppositions to truth, and to do our little, with sympathy and inspiration, to forward the creation.

All beliefs, all doctrines, all creeds are mine. I want only the truth and the privilege to live in the great good world. Truth, and the quest of truth, are always safe. It is not my part to be anxious about destiny or about the universe. If my tiny opinions are outgrown, I shall wait, in patience and in hope.

There is grateful release in letting the universe take care of itself. The universe is in better hands than mine. In these matters, I will substitute trust for faith. If I cannot remove the dandelions from the lawn, then I will love the dandelions. Where once were weeds are now golden coins, bees reveling in color, and the spring sunshine kissing the blossoms with lips of dew. It is so sweet and restful that $I$ abide in peace.

Passengers on the cosmic sea

We know not whence nor whither :

'Tis happiness enough to be

In tune with wind and weather. 

THE following pages contain advertisements of a few of the Macmillan books on kindred subjects. 



\section{THE RURAL OUTLOOK SET}

By Professor L. H. Bailey, Director of the New York State College of Agriculture at Cornell University.

Four Volumes. Each, cloth, I2mo. Uniform binding, attractively boxed. Each volume also sold separately.

In this set are included three of Professor Bailey's most popular books as well as a hitherto unpublished one, - "The CountryLife Movement." The long and persistent demand for a uniform edition of these little classics is answered with the publication of this attractive series.

\section{The Country-Life Movement}

This hitherto unpublished volume deals with the present movement for the redirection of rural civilization, discussing the real country-life problem as distinguished from the city problem, known as the back-to-the-land movement.

\section{The Outlook to Nature (New and revised edition)}

In this alive and bracing book, full of suggestion and encouragement, Professor Bailey argues the importance of contact with nature, a sympathetic attitude toward which "means greater efficiency, hopefulness, and repose."

\section{The State and the Farmer (New edition)}

It is the relation of the farmer to the government that Professor Bailey here discusses in its varying aspects. He deals specifcally with the change in agricultural methods, in the shifting of the geographical centers of farming in the United States, and in the growth of agricultural institutions.

\section{The Nature Study Idea (New edition)}

"It would be well," the critic of The Tribune Farmer once wrote, "if 'The Nature Study Idea' were in the hands of every person who favors nature study in the public schools, of every one who is opposed to it, and, most important, of every one who teaches it or thinks he does." It has been Professor Bailey's purpose to interpret the new school movement to put the young into relation and sympathy with nature, - a purpose which he has admirably accomplished.

PUBLISHED BY

THE MACMILLAN COMPANY 64-66 Fifth Avenue, Now York 


\section{BOOKS ON AGRICULTURE}

\section{On Selection of Land, etc.}

Thomas F. Hunt's How to Choose a Farm .

E. W. Hilgard's Soils: Their Formation and Relations to Climate and Plant Growth

On Tillage, etc.

F. H. King's The Soil • • . . . . . I 50 net

Isaac P. Roberts' The Fertility of the Land . . . . I 50 net

Elwood Mead's Irrigation Institutions . - . . I 25 net

F. H. King's Irrigation and Drainage . . . . I 50 net

William E. Smythe's The Conquest of Arid America . I 50 net

Edward B. Voorhees' Fertilizers . • . . . I 25 net

Edward B. Voorhees' Forage Crops : . . 150 net

H. Snyder's Chemistry of Plant and Animal Life : : $\quad$ I 25 net

H. Snyder's Soil and Fertilizers. Third edition . - I 25 net

L. H. Bailey's Principles of Agriculture • • . $\quad$ I 25 net

W. C. Welborn's Elements of Agriculture, Southern and Western

J. F. Duggar's Agriculture for Southern Schools :

G. F. Warren's Elements of Agriculture

Management . . . . .

Hilgard \& Osterhout's Agriculture for Schools on the Pacific Slope

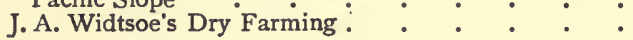

75 net

75 net

I Io net

I 75 net

I $\infty$ net

I 50 net

\section{On Garden-Making}

L. H. Bailey's Manual of Gardening . . . . 200 net

L. H. Bailey's Vegetable-Gardening . . . . I 50 net

L. H. Bailey's Horticulturist's Rule Book . . . 75 net

L. H. Bailey's Forcing Book . . • . • . I 25 net

A. French's Book of Vegetables . . . . . I 75 net

On Fruit-Growing, etc.

L. H. Bailey's Nursery Book . . . . . . I 50 net

L. H. Bailey's Fruit-Growing . . . . . . I 50 net

L. H. Bailey's The Pruning Book . . . . . I 50 net

F. W. Card's Bush Fruits . . . . . . I 50 net

J. T. Bealby's Fruit Ranching in British Columbia : I 50 net

\section{On the Care of Live Stock}

D. E. Lyon's How to Keep Bees for Profit - • - I 50 net

Nelson S. Mayo's The Diseases of Animals . . . I 50 net

W. H. Jordan's The Feeding of Anlmals . . . I 50 net

I. P. Roberts' The Horse . . . . . . I 25 net

George C. Watson's Farm Poultry - . . $\quad$ I 25 net

C. S. Valentine's How to Keep Hens for Profit • • I 50 net

O. Kellner's The Scientific Feeding of Animals (trans.) I go net

M. H. Reynolds' Veterinary Studies for Agricultural Students 


\section{On Dairy Work}

Henry H. Wing's Milk and its Products . . . \$ I 50 net

C. M. Aikman's Milk

Harry Snyder's Dairy Chemistry . . . . . I oo net

W. D. Frost's Laboratory Guide in Elementary Bacteriology

The Farm and the Dairy $\cdot{ }^{\circ}$

Chr. Barthel's Methods Used in the Examination of

Milk and Dairy Products . . . . . . I go net

On Plant Diseases, etc.

George Massee's Plant Diseases . . . . I 60 net

J. G. Lipman's Bacteria in Relation to Country Life : I 50 net

E. C. Lodeman's The Spraying of Plants . . . I 25 net

H. M. Ward's Disease in Plants (English) . . . $\quad$ I 60 net

A. S. Packard's A Text-book on Entomology . . 450 net

On Production of New Plants

L. H. Bailey's Plant-Breeding . . . I 25 net

L. H. Bailey's The Survival of the Unlike : : 200 net

L. H. Bailey's The Evolution of Our Native Fruits : 200 net

W. S. Harwood's New Creations in Plant Life . . I 75 net

\section{On Economics and Organization}

J. McLennan's Manual of Practical Farming . . I 50 net

L. H. Bailey's The State and the Farmer . . . I 25 net

Henry C. Taylor's Agricultural Economics • • • I 25 net

I. P. Roberts' The Farmer's Business Handbook . I 25 net

George T. Fairchild's Rural Wealth and Welfare . I 25 net

S. E. Sparling's Business Organization . • . • I 25 net

In the Citizen's Library. Includes a chapter on Farming

Kate V. St. Maur's A Self-supporting Home • • I 75 net

Kate V. St. Maur's The Earth's Bounty . . . I 75 net

G. F. Warren and K. C. Livermore's Exercises in Farm Management

H. N. Ogden's Rural Hygiene $\quad$ : $\quad$ • $\quad$ • $\quad$ : :

80 net I 50 net

\section{On Everything Agricultural}

L. H. Bailey's Cyclopedia of American Agriculture :

Vol. I. Farms, Climates, and Soils.

Vol. II. Farm Crops.

Vol. III. Farm Animals.

Vol. IV. The Farm and the Community.

To be complete in four royal 8 vo volumes, with over 2000 illustrations. Price of sets: cloth, $\$ 20$ net; half-morocco, $\$ 32$ net.

For further information as to any of the above, address the publishers

PUBLISHED BY

THE MACMILLAN COMPANY

64-66 Fifth Avenue, New York 


\section{NEW BOOKS ON AGRICULTURE}

\section{How to Keep Bees for Profit}

By D. E. LYON

Cloth, Illustrated, I2mo.

Dr. Lyon is an enthusiast on bees. He has devoted many years to the acquisition of knowledge on this subject, and his book is a practical one. In it he takes up the numerous questions that confront the man who keeps bees, and deals with them from the standpoint of long experience.

\section{How to Keep Hens for Profit}

\section{By C. S. VALENTINE Cloth, Illustrated, r2mo.}

Mr. Valentine is a well-known authority upon the subject. His knowledge is extensive and accurate; the information that he gives will be of service, not only to the amateur who keeps poultry for his own pleasure, but to the man who wishes to derive from it a considerable portion of his income.

\section{Manual of Gardening}

By L. H. BAILEY

Cloth, Illustrated, I2mo, $\$ 2.00$ net

This new work is a combination and revision of the main parts of two other books by the same author, "Garden Making " and "Practical Garden-Book," together with much new material and the results of the experience of ten added years.

\section{The Book of Vegetables and Garden Herbs}

\section{By ALLEN FRENCH Cloth, Illustrated, 12mo, \$1.75 net}

A practical book "from the ground up." It gives complete directions for growing all vegetables cultivatable in the climate of the northern United States. It represents a departure in vegetablegarden literature. It does not generalize. Leaving the description of garden processes to the general handbooks, it considers the vegetables not in classes but individually, according to their importance.

\section{PUBLISHED BY}

\section{THE MACMILLAN COMPANY}

\section{4-66 Fifth Avenue, Now York}









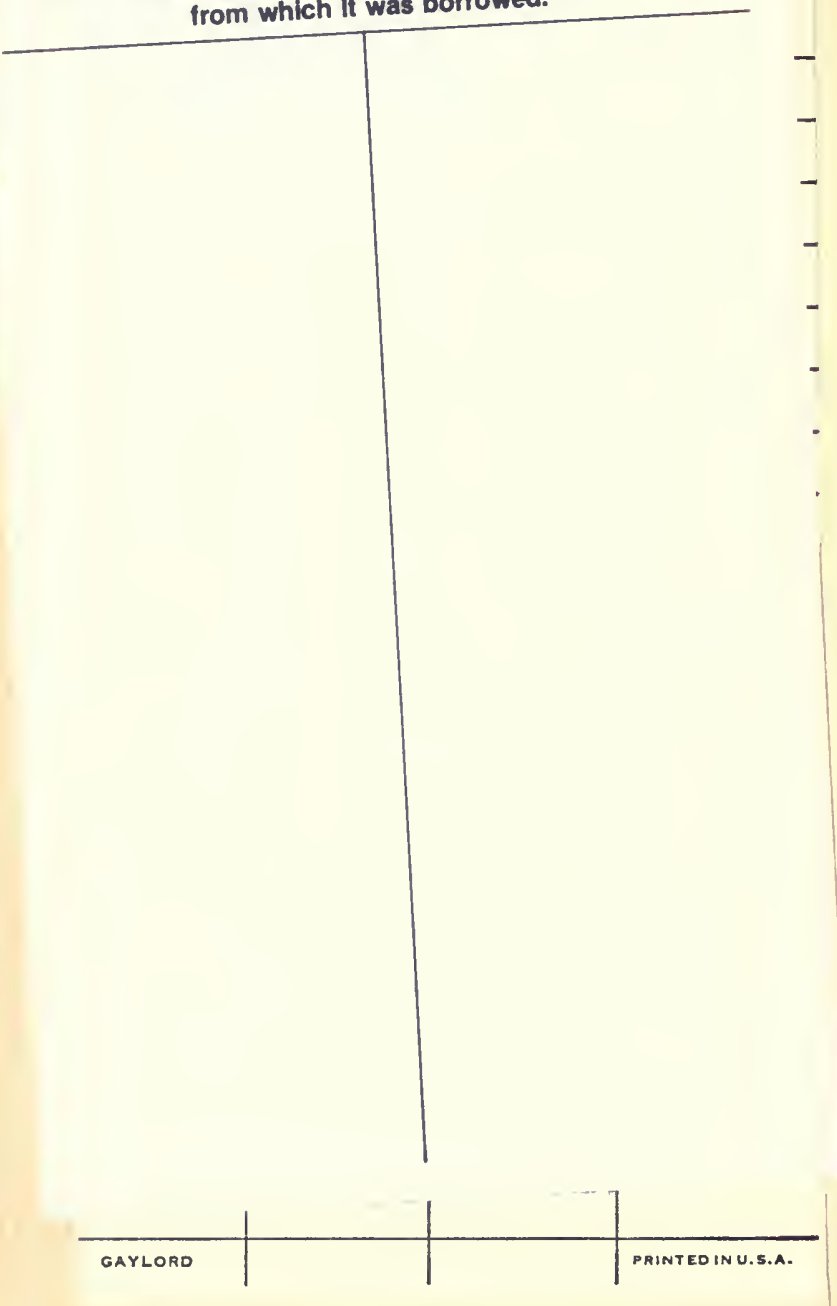


UC SOUTHEAN REGIONAL LIBRARY FACILITY

|

A 000858300

A $000858309 \quad 8$

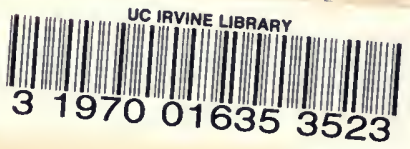


